\title{
Production, Transmission, Pathogenesis, and Control of Dengue Virus: A Literature-Based Undivided Perspective
}

\author{
Muhammad Torequl Islam, ${ }^{1}$ Cristina Quispe, ${ }^{2}$ Jesús Herrera-Bravo ${ }^{D},{ }^{3,4}$ Chandan Sarkar, ${ }^{1}$ \\ Rohit Sharma (D), ${ }^{5}$ Neha Garg, ${ }^{6}$ Larry Ibarra Fredes, ${ }^{7}$ Miquel Martorell $\left(\mathbb{D},{ }^{8,9}\right.$ \\ Mohammed M. Alshehri $\mathbb{D}^{10}{ }^{10}$ Javad Sharifi-Rad $\mathbb{D}^{11},{ }^{11}$ Sevgi Durna Daştan, ${ }^{12,13}$ \\ Daniela Calina $\mathbb{D}^{14},{ }^{14}$ Radi Alsafi ${ }^{10},{ }^{15}$ Saad Alghamdi $\mathbb{D}^{15}$ Gaber El-Saber Batiha, ${ }^{16}$ \\ and Natália Cruz-Martins $\mathbb{D}^{17,18,19}$
}

${ }^{1}$ Department of Pharmacy, Life Science Faculty, Bangabandhu Sheikh Mujibur Rahman Science and Technology University, Gopalganj (Dhaka)8100, Bangladesh

${ }^{2}$ Facultad de Ciencias de la Salud, Universidad Arturo Prat, Avda. Arturo Prat 2120, Iquique 1110939, Chile

${ }^{3}$ Departamento de Ciencias Básicas, Facultad de Ciencias, Universidad Santo Tomas, Chile

${ }^{4}$ Center of Molecular Biology and Pharmacogenetics, Scientific and Technological Bioresource Nucleus, Universidad de La Frontera, Temuco 4811230, Chile

${ }^{5}$ Department of Rasa Shastra \& Bhaishajya Kalpana, Faculty of Ayurveda, Institute of Medical Sciences, Banaras Hindu University, Varanasi-221005, Uttar Pradesh, India

${ }^{6}$ Department of Medicinal Chemistry, Institute of Medical Sciences, Banaras Hindu University, Varanasi-221005, Uttar Pradesh, India

${ }^{7}$ European Institute of Traditional Chinese Studies, 4000-501 Porto, Portugal

${ }^{8}$ Department of Nutrition and Dietetics, Faculty of Pharmacy, and Centre for Healthy Living, University of Concepción, 4070386 Concepción, Chile

${ }^{9}$ Universidad de Concepción, Unidad de Desarrollo Tecnológico, UDT, Concepción 4070386, Chile

${ }^{10}$ Pharmaceutical Care Department, Ministry of National Guard-Health Affairs, Riyadh, Saudi Arabia

${ }^{11}$ Facultad de Medicina, Universidad del Azuay, Cuenca, Ecuador

${ }^{12}$ Department of Biology, Faculty of Science, Sivas Cumhuriyet University, 58140 Sivas, Turkey

${ }^{13}$ Beekeeping Development Application and Research Center, Sivas Cumhuriyet University, 58140 Sivas, Turkey

${ }^{14}$ Department of Clinical Pharmacy, University of Medicine and Pharmacy of Craiova, 200349 Craiova, Romania

${ }^{15}$ Laboratory Medicine Department, Faculty of Applied Medical Sciences, Umm Al-Qura University, Makkah, Saudi Arabia

${ }^{16}$ Department of Pharmacology and Therapeutics, Faculty of Veterinary Medicine, Damanhour University, Damanhour, Egypt

${ }^{17}$ Faculty of Medicine, University of Porto, Porto, Portugal

${ }^{18}$ Institute for Research and Innovation in Health (i3S), University of Porto, Porto, Portugal

${ }^{19}$ Institute of Research and Advanced Training in Health Sciences and Technologies (CESPU), Rua Central de Gandra, 1317, 4585-116 Gandra PRD, Portugal

Correspondence should be addressed to Javad Sharifi-Rad; javad.sharifirad@gmail.com, Daniela Calina; calinadaniela@gmail.com, and Natália Cruz-Martins; ncmartins@med.up.pt

Received 13 July 2021; Revised 11 November 2021; Accepted 26 November 2021; Published 15 December 2021

Academic Editor: Cassiano Felippe Gonçalves-de-Albuquerque

Copyright (c) 2021 Muhammad Torequl Islam et al. This is an open access article distributed under the Creative Commons Attribution License, which permits unrestricted use, distribution, and reproduction in any medium, provided the original work is properly cited.

Dengue remains one of the most serious and widespread mosquito-borne viral infections in human beings, with serious health problems or even death. About 50 to 100 million people are newly infected annually, with almost 2.5 billion people living at risk and resulting in 20,000 deaths. Dengue virus infection is especially transmitted through bites of Aedes mosquitos, hugely 
spread in tropical and subtropical environments, mostly found in urban and semiurban areas. Unfortunately, there is no particular therapeutic approach, but prevention, adequate consciousness, detection at earlier stage of viral infection, and appropriate medical care can lower the fatality rates. This review offers a comprehensive view of production, transmission, pathogenesis, and control measures of the dengue virus and its vectors.

\section{Introduction}

Dengue regards one of the utmost serious arboviral infections around the world. dengue virus (DENV) is transmitted through bites of female Aedes mosquitos especially Aedes (Stegomyia) aegypti, Ae. alpopictus [1], Ae. niveus, and Ae. polynesiensis [2]. DENV infection is almost similar to flulike infection and sometimes develops into possibly lethal difficulties or severe illness including dengue shock syndrome and dengue hemorrhagic fever. World Health Organization (WHO) reports that DENV infection has been shown to 30-fold increase around the globe over the past five decades, and approximately 100 million newly infected people are estimated in over 100 endemic countries with 20,000 deaths annually [3].

DENV and its vectors are primarily noticed in tropical and subtropical environments globally, frequently in urban and semiurban areas. In Bangladesh, DENV has been detected as a severe health hazard. Between 2000 and 2008, 50,148 people were hospitalized for dengue in Bangladesh. But in August 2019, nearly 60,000 dengue patients have been hospitalized, and approximately 100 deaths have been reported. Severe DENV infection is a leading cause of tenacious sickness and deaths of people of all ages in Asian and Latin American countries. Unfortunately, we have no particular treatment strategy for dengue infection. It may be because historically our pharmaceutical section did not come up with much attention to this vector-borne viral disease.

This review is aimed at sketching a current scenario on DENV, dengue infection, and dengue vectors along with the production, transmission, pathogenesis, and ways of control of DENV, and its vectors offers a comprehensive view of production, transmission, pathogenesis, and control measures of DENV and its vectors.

\section{Dengue Virus (DENV)}

DENV, a pathogenic arthropod-borne flavivirus (arbovirus), is a single-stranded and positive-sense RNA molecule belonging to the family Flaviviridae.

The Flaviviridae family includes viruses transmitted by arthropods that cause serious illness in humans. The family includes a single genus-Flavivirus, with several types [4]. Recently, another subdivision of the family into three genera has been proposed as follows: genus Flavivirus includes arboviruses (yellow fever virus, dengue fever virus); genus Pestivirus-viruses involved in animal pathology; and genus Hepacavirus-the proposed name for different variants of hepatitis $C$ virus [4].

To date, 47 strains of DENV have been identified. The total number of four closely linked serotypes (from DENV -1 to -4$)$ of DENV has been identified to date, but they are lightly antigenically distinct $[5,6]$, and those can be subdivided into several genotypes according to their gene sequences [7]. These serotypes are generally progressed from a mutual ancestor, and all are considered as the causative agent of approximately similar disease spectrum in humans due to DENV selecting different receptors based on cell types and virus strains [8]. Developed viral particles have a spherical shape with $11 \mathrm{~kb}$ in length and $40-50 \mathrm{~nm}$ in diameter, containing single-stranded and positive-sense RNA molecule, which has a 5-methyl cap with a single open reading frame [2]. Dengue virus and its common four serotypes have shown in Figure 1.

2.1. DENV Vectors. Dengue virus infection usually spreads through bites of infected female mosquitos of genus Aedes, especially by the Aedes aegypti and Ae. albopictus [1]. However, the other two vectors such as Ae. polynesiensis and Ae. niveus have been identified as the secondary vectors in some regions throughout the world [2] (Figure 2).

Adult $A e$. aegypti has a white scale that forms a lyre or violin shape at the dorsal side of the thorax, while the adult Ae. albopictus forms a white stripe at the middle point of the top of the thorax region. The white bands of every tarsal segment of the hind legs of these mosquitos are known as the white stripe. The abdomen is generally found to be black or dark brown, but sometimes, it also bears white scales. Females are usually larger than males; on the other way, through finding small palps tipped with silver or white scales, they can be discriminated against properly. Males are specially identified by the plumose type of antennae. On the other hand, females are seen to bear short hair. Under a microscope, the mouthparts of the male are watched as a structural modification for nectar feeding, and female mouthparts are viewed as a modified structure for feeding on blood. The darkly coloured proboscis is found to be present in both sexes. In addition, two clusters of white scales presented on the segment above the proboscis are known as clypeus. The tip of the abdomen is pointed out as a distinctive feature of all Aedes species [9].

2.2. Geographical Distribution. DENV mainly originated from monkeys, then jumped to humans in Southeast Asia or Africa between 100 and 800 years ago. Geographically DENV has been restricted till the 1950s, but after the Second World War caused a rapid distribution throughout the world. Firstly, DENV infection was recognized in the Thailand and Philippines in the 1850s, and after the 1980s towards Latin America and the Caribbean. Presently, DENV is prevalent throughout the different countries (at least 100 countries) including in Asia, the Pacific, the Americas, Africa, and the Caribbean. DENV epidemics occurred in 26 states [10]. Scientific reports demonstrate that DENV-2 and 3 serotypes were mostly outbroken before 2000 and 

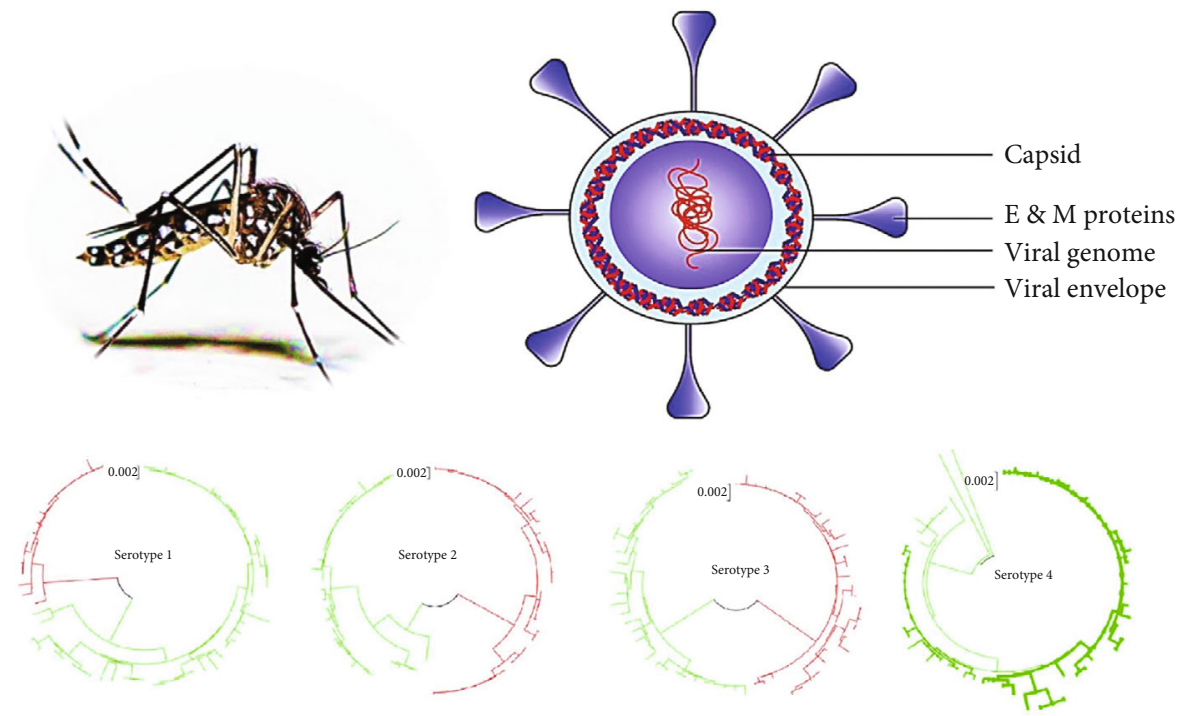

FIgURE 1: Diagram with dengue virus and its four serotypes.

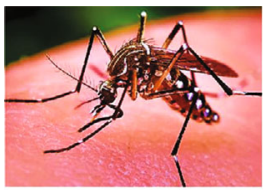

Aedes aegypti

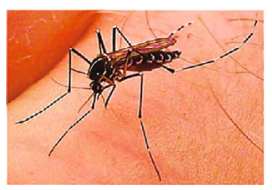

Aedes polynesiensis

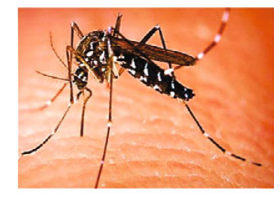

Aedes albopictus

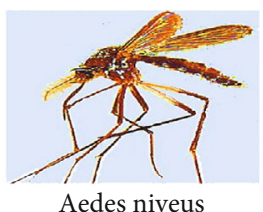

Aedes niveus
FIgURE 2: Aedes mosquitoes (dengue virus vectors).

between 2000 and 2009, respectively. DENV-1 serotype started to dominate worldwide dengue outbreaks and after 2010, the DENV-4 [11].

The geographical distribution of DENV worldwide has been shown in Figure 3.

Ae. Aegypti is scattered in tropical areas geographically, and it breeds artificially in containers (such as tyres, drums, flower vases including plastic food containers, tin cans, and old motor parts) that are filled with water [12].

Ae. aegypti is an insect of holometabolous type, which is fully developed after completing metamorphosis (i.g., four growing phases from egg to adult period). The duration of the life span of an adult may be 2 to 4 weeks; however, it depends on the environmental conditions, at least 4-5 times a female mosquito lays eggs throughout her whole life span and the average 10 to 100 eggs in a single spawn. Three diverse polytypic forms are found in Ae. aegypti such as sylvan, domestic, and peridomestic [13].

A sylvan type is generally a rural form which breeds in tree holes, normally in forests; the domestic type commonly breeds in municipal surroundings, frequently inside or around houses; and the peridomestic type usually survives in biologically modified regions as groves and coconut farms [14]. Ae aegypti can survive above $4^{\circ} \mathrm{C}$ [15]; on the other hand, about $15-37^{\circ} \mathrm{C}$ temperature is required for a complete life cycle [16].

The extent of DENV epidemics not only depends on the presence of DENV and mosquito genotypes but also depends on how they interrelate with local temperature [17]. Nevertheless, a current study demonstrated that DENV infection can alter gene expression in the Ae. aegypti mosquito's head that causes a loss of their olfactory preferences, thereby modifying oviposition site choice [18]. Now, the question is how safe is the host nervous system's homeostasis during Dengue infection?

2.3. Life Cycle. Primarily, the DENV was transmitted via sylvatic cycles in Asia and Africa by Aedes mosquito and the nonhuman primates, with occasional appearances of human populations [19]. However, nowadays, the global spread of DENV follows its emergence of all types of transmissions (e.g., sylvatic cycles and vertical: mosquito to mosquito). Thus, its primary life cycle entirely involves the transmission between Aedes mosquitoes and humans [20]. One report suggests that dogs or other animals may act as incidental hosts and may serve as reservoirs of DENV infection [21]. Life cycles of mosquitoes have been shown in Figure 4.

2.4. Immune Defensive Pathways. The Toll pathway is one of the well-known potential immune defensive pathways against the DENV and its serotypes bearing Ae. aegypti [22]. In a study, after ten days postinfection of DENV, the antioxidant enzymes were found to suppress, while upregulated the expressions of Toll, JAK-STAT, and pathogen recognition receptor (PRR) [23]. It has also been analyzed that the JAK-STAT pathway is another important DENV defensive pathway in invertebrates $[24,25]$. The mosquitoes of genus Aedes should be more vulnerable to DENV infection if the receptor JAK homolog HOP or Dome is inhibited by RNA inference (RNAi, e.g., ds RNA and prM RNA) $[25,26]$. 


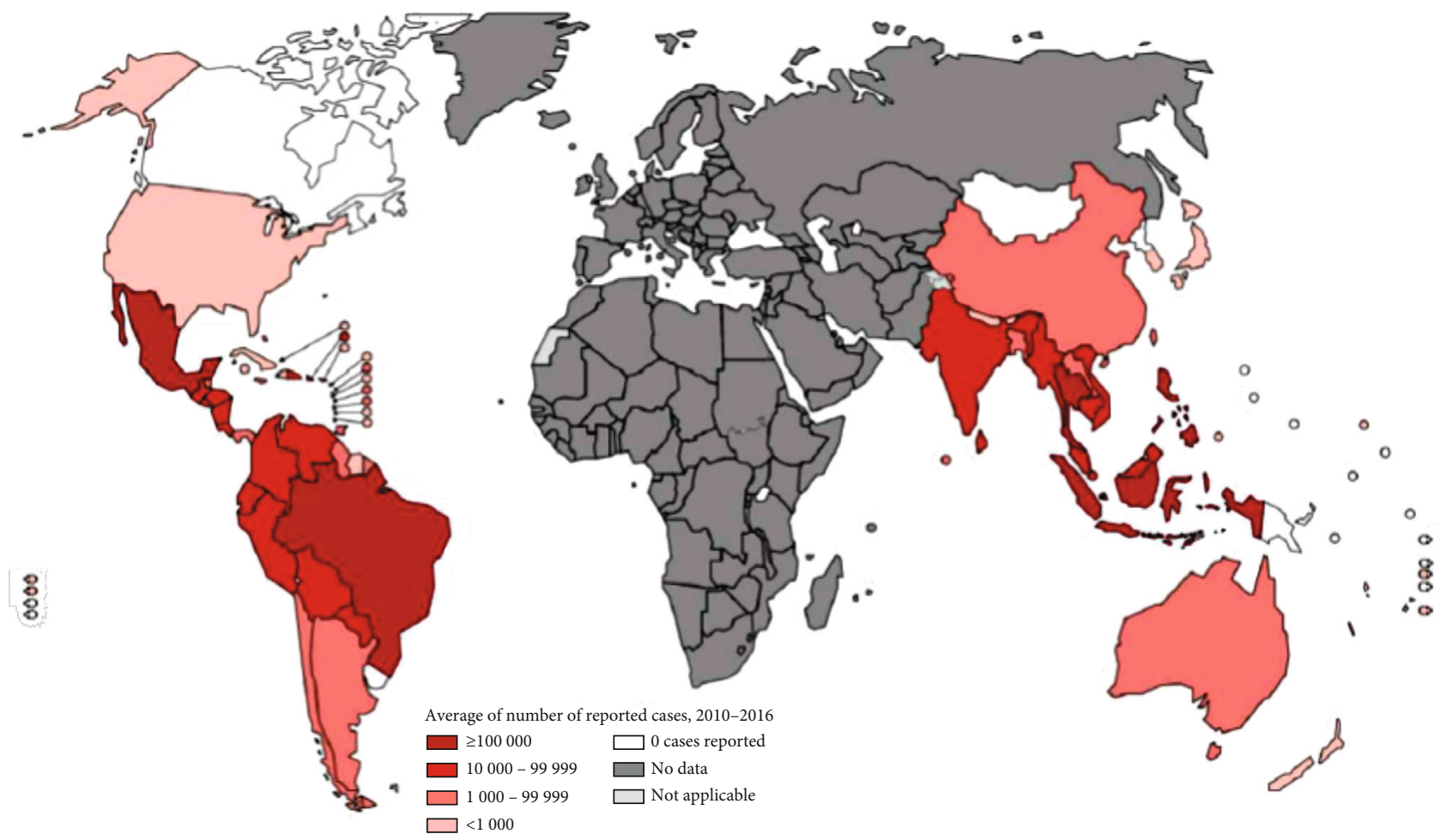

FIgURE 3: Geographical distribution of dengue worldwide.

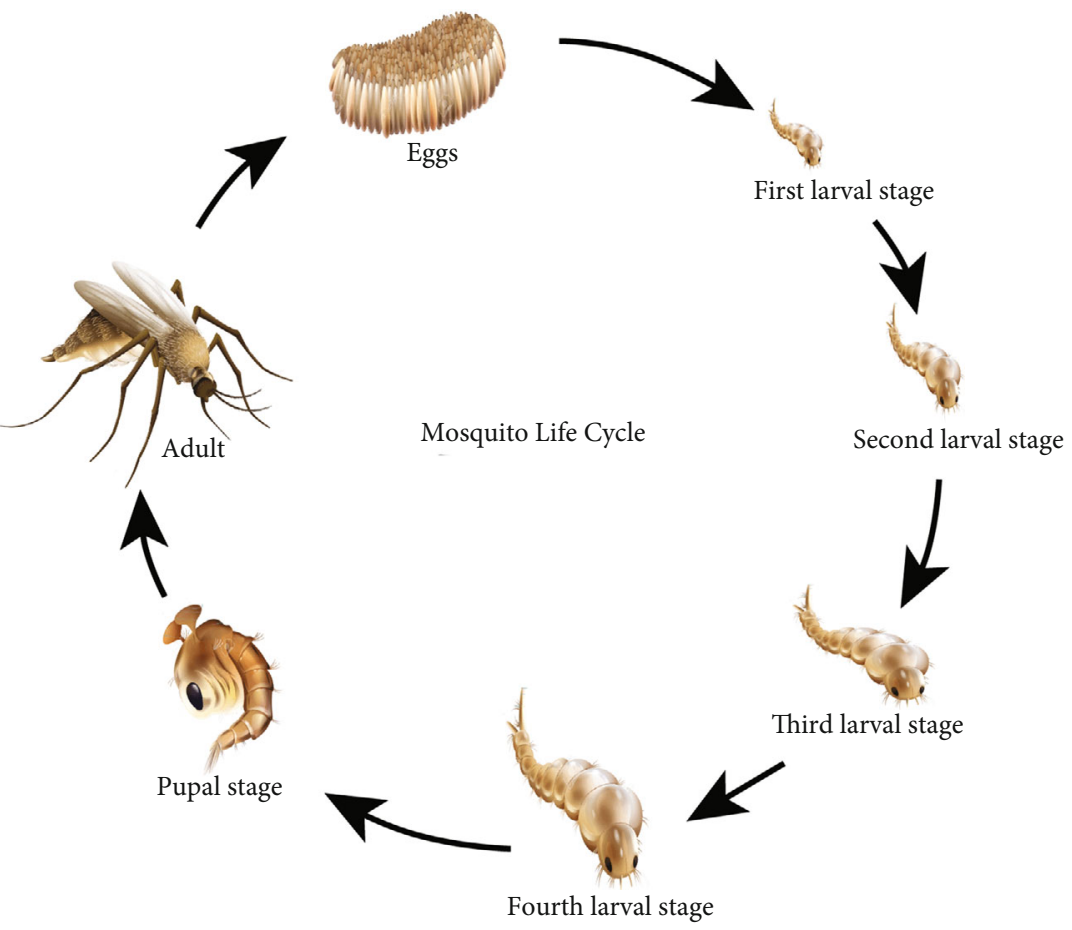

Figure 4: Mosquito life cycle.

In a study, miR-375 was found to enhance DENV2 replication capacity [27]. In another study, in the period of DENV infection, miRNAs were identified in different forms (about sixty-six) in Ae. albopictus, where upregulated miR- 34-5p targets the Toll pathway signalling protein (REL-1) [28]. Conversely, downregulated peptidoglycan recognition protein LE, and AMP defensin D. miR87 targets the Toll pathway [28]. 
Differential expression of miRNAs in DENV has been also reported by Yen et al. [29]. In this study, the authors highlighted the possibility of using artificial antiviral miRNAs to reduce the transmission of two major arboviruses in transgenic Ae. Aegypti. The miRNA-based approach resulted in a dual resistance phenotype for Dengue serotype 3 viruses (DENV-3).

The piRNAs also plays essential roles in the innate antiviral response in DENV [30-33]. Moreover, nonretroviral integrated RNA viruses (NIRVS) were recognized in Ae. aegypti and Ae. albopictus in a larger number [34].

The expression of cecropin-like AMPs was expressively upregulated by the infection of DENV [24]. In Ae. aegypti, the immune deficiency (IMD) pathway shows a significant role to resist DENV susceptibility, while the increase in viral replication [35]. The ubiquitin variant (Ub3881) residues may inhibit the DENV envelope protein, thereby and decrease the production rate of DENV in Aedes vectors $[36,37]$.

The DENV-containing blood meal first appears in the midgut of the vectors, which has the first line of defense systems, such as the infection barrier and the escape barriers $[38,39]$. It is evident that, after a successful entry of DENV, something has happened inside the midgut cells such as uncoating, replication, and new virus particle assembly. The innate immune signalling pathways have been seen to be effective during the infection of DENV in Ae. aegypti. Exogenous siRNA pathways also play a substantial role against DENV infections in the Aedes midgut [40]. DENV infection causes the production of NO in the hemolymph, where the virus is released into the hemocoel from the midgut. The hemocytes allow replication other than the distribution of DENV. Interestingly, DENV replication in hemocytes is extensively inhibited by NO [41]. It has been reported that about 40 differentially bacterial types have been isolated from the gut of Ae. aegypti through a gut microbiome study [42]. In another study, colonization of Csp_P in the midgut of the Ae. aegypti also inhibited DENV infection [43]. The Talaromyces (Tsp) secretome shows a considerable modulating effect on the midgut transcriptome. $T s p$ secretome may display a significant role in the advancement of DENV infection in the midgut through downregulating trypsin encoding genes involved in the digestion of blood and through reducing the enzymatic activity of trypsin [44]. It is cited that the presence of gram-negative endosymbiotic bacteria Wolbachia spp. in Aedes mosquitoes effectively suppressed the DENV infection [45]. Wolbachia activates antimicrobial peptides defensin and cecropin Toll pathway through producing reactive oxygen species (ROS) after inducing a reduction-oxidation (Redox) reaction in the mosquitos [46]. Wolbachia also upsurges vagol expression in Ae aegypti by acting as a ligand of the JAK-STAT pathway [47].

Ae. aegypti macroglobulin complement related factor (AaMCR) recognizes DENV particles. An anti-DENV effect on Aedes mosquitoes has been found to link with the upregulation of AMP expression in the hemocytes [48]. The salivary glands also contain the infection barrier and the escape barriers [49]. Moreover, incomplete apoptosis of
DENV occurs here, which is required for the virus to release via saliva [50]. A study revealed that multiple immune defensive pathways (e.g., Toll and IMD) can be found here, and this can rise putative antibacterial proteins/peptides (e.g., attacin, cecropins, defensins, and gambicin) [24, 28, $35,48,51]$. In the brain of Ae. aegypti, a homolog of Hikaru Genki (AaHig) has been found to express ubiquitously [52].

Lipid droplets (LDs) containing a few exclusive structural proteins (Perilipin 1, 2, and 3) and a fatty acid monolayer are exclusively found to present in a variety of organisms including DENV. These have been found to provide immunological defense of Aedes mosquitoes [53-55].

\section{DENV Infection}

3.1. Transmission. After initial midgut infection, DENV distributes systemically through the body cavity (commonly known as hoemocel) of Aedes vectors, after that way disseminates in secondary tissues. The time taken between initial midgut infection and successive transmission of DENV by its vector (e.g., Ae. aegypti) is termed as extrinsic incubation period ( 7 to 14 days at $25-30^{\circ} \mathrm{C}$ ). DENV stays in the midgut of the vectors which it may be due to the viral genome being stable here [36].

The ubiquitin-proteasome, an important pathway, acts significant activity in the regulation of infectious DENV production in vectors [36]. Finally, an infection of the salivary glands and the release of virions into the host's saliva occur throughout the DENV transmission to the host [56]. Blood cells and plasma are important media for the four serotypes of DENV spreading into the host. A relation of domain III from the envelope glycoprotein of DENV-II with human plasma proteins has been identified by Huerta et al. [57] [57]. DENV infection inductees after the attachment of the dengue virus to the target cell through interfaces between the various cell surface receptors and viral envelope (E) protein [58]. In mammalian cells, all categorized serotypes interact with mannose, heparan sulfate, nLc4Cer, and DCSIGN/L-SIGN receptors.

Additionally, the DENV-2 serotype is found to intensity of binding with GRP78, CD14-associated protein, HSP70/ HSP90, and two other unidentified receptor proteins. Conversely, serotypes DENV 1-3 bind with the laminin receptor while serotypes DENV 2-4 attach with an unknown protein receptor [59].

DENV after receptor-mediated endocytosis, virion fuses with acidic lysosomes, and its genomic RNA is released into the cytoplasm and translated into a polyprotein of $\sim 3400$ amino acids (genome is about 11000 bases of positive-sense, a single-stranded RNA (ssRNA)) that are further cleaved by viral and host proteases into three structural (capsid: C, membrane: $M$, and envelope: $E$ ) and seven nonstructural (NS1, NS2A, NS2B, NS3, NS4A, NS4B and NS5) proteins [60].

$\mathrm{C}$ protein is a foremost structural component of DENV that is localized in the cytoplasm and nuclei [61, 62]. The nuclear localization of this protein is thought to be crucial for its well-organized replication $[61,63]$. 
The lipid bilayer of virions is formed by lipid (approximately $17 \%$ by weight) between the nucleocapsid core and E/M outer shell $[64,65]$. During the replication of DENV, a membrane-bound replication complex formation helps to incorporate host factors, viral proteins, and genomic RNA [66]. In this case, positive-strand (+) DENV genomic RNA acts as a template to synthesize complementary negativestrand (-) RNA, which is sequentially used for multiple (+) RNA genomes production that is obtainable for translation and regulation of replication cycles or packaging into virions [67]. However, in a study, Raquin and Lambrechts [68] showed the presence of DENV genomic RNA in the salivary galnds of $A e$. aegypti, indicating an active replication of DENV in its vector prior to transmission [68]. DENV itself encodes RNA-dependent RNA polymerases, and the infection cycle of this virus is catalyzed by other cellular factors [69].

DENV infections can alter many important proteins in the subcellular locales, including the Alix apoptosis-linked gene-2-interacting protein $\mathrm{X}$; therefore, blocking this step may be one of the innovative beneficial approaches to reduce DENV replication in the host [70]. Instead, several genes have been identified that reduce infection of DENV when silenced by at least $60 \%$ in its most important vector $A e$. aegypti. Among them, a putative cysteine-rich venom protein SeqID AAEL000379 (CRVP379) silencing has been found to reduce DENV infection significantly in the cells of midgut tissues of Ae. aegypti [71].

Loqs2, a gene has been found only in Aedes mosquitoes, which is essential for the appropriate effectiveness of RNA interference in this type of mosquito. However, without Loqs2, the viruses can multiply and consequently infect their salivary glands [72].

An interaction between DENV nonstructural protein 4A (NS4A) and host cellular vimentin has been demonstrated in localizing and concentrating the viral replication complex at the perinuclear site, in consequence assisting well-organized replication of viral RNA [73].

Figure 5 shows a general DENV transmission mode in its vector to hosts.

3.2. Pathogenesis. DENV is usually greater in tropical and subtropical environments throughout the world, frequently in urban and semiurban zones. People, exposed to infected mosquitoes of all ages are susceptible to DENV infection. DENV infection causes dandy fever, breakbone fever, and dengue hemorrhagic fever; and in severe cases, dengue shock syndrome has occurred. The rainy season is the most favorable climate for DENV infection outbreaks in tropical countries in Asia and South America. Generally, the infected female Aedes mosquitoes transmit DENV in humans. Although humans are not capable of transmitting DENV, it can be transmitted during the blood transfusion between an infected person to a noninfected (healthy) person $[74,75]$.

3.3. Physiological Data. After the incubation period (3 to 14 days) of DENV, the person may experience one or more early symptoms such as nausea, headache, rash, fever, mus- culoskeletal pain, and joint pain [76]. In classic dengue fever, body temperature ranges from 39 to $40^{\circ} \mathrm{F}$ (5-7 days) [77]. In the meantime, the DENV may enter systematically into the bloodstream at the peripheral zones and sequentially damage lymph nodes and blood vessels resulting in dengue hemorrhagic fever [78]. Symptoms of the latter case include bleeding under the skin and from the gums and nose. On the other hand, difficulty in breathing appears in patients having dengue hemorrhagic fever, and severe progress of it can lead to dengue shock syndrome, if left untreated, can result in death.

3.4. Micronutrient Imbalance. The morphogenesis and translation and/or replication of DENV occur in the endoplasmic reticulum (ER) [79], where $\mathrm{Ca}^{2+}$ plays a significant activity in cell signaling. The immune response of T-cell has been drawn in DENV infection. At the time of secondary infection (i.e., infection after 1-2 days of fever onset), high concentration of interferon-alpha (IFN- $\alpha$ ) is found, while high levels of soluble interferon $\gamma(\operatorname{IFN}-\gamma)$, interleukin 2 receptor (IL-2R), and soluble CD4 and CD8 were reported throughout the outset of vascular permeability [80, 81]. Dengue antigen is evident to increase the influx of $\mathrm{Ca}^{2+}$ into $\mathrm{T}$ cells, thus reducing blood $\mathrm{Ca}^{2+}$ levels $[82,83]$.

A multifunctional intermediate messenger protein calmodulin is well known as a primary sensor of intracellular $\mathrm{Ca} 2+$ in the eukaryotic cells, which plays imperative utility for proper decoding of $\mathrm{Ca} 2+$ signalling [84]. DDX3X is a DEAD-box RNA helicase, which binds with the TRPV4 cation channel that regulates its functions. DDX3X is released by the TRPV4-mediated $\mathrm{Ca}^{2+}$ influx; at the same time, DDX3X nuclear translocation is derived through a process involving calmodulin and its kinase II-dependent pathway.

Therefore, pharmacological inhibition or genetic depletion of TRPV4 can diminish DDX3X-dependent functions, including translation and nuclear viral export. Thus, targeting TRPV4 may reduce the infectivity of some viruses, including dengue, Zika viruses, and hepatitis $C$ [85]. In a study, the effect of $\mathrm{W}-7$, a calmodulin antagonist in DENV infection in Huh-7 cells, was seen, where W7 was inhibited viral yield, NS1 secretion and viral RNA, and protein synthesis, possibly through direct inhibition of NS2B-NS3 activity and/or inhibition of the interaction between NS2A with $\mathrm{Ca}^{2+}$-calmodulin complex [86]. Calcium depletion can modulate cardiac functions, immunopathogenesis, and platelet functions in dengue infection [82]. Another study on $36 \mathrm{~h}$ postinfection of Huh7 cells has been demonstrated that calcium modulating cyclophilin-binding ligand influences the apoptosis process by changing the activation of caspase- 3 and the potentiation of mitochondrial membrane [87].

3.5. Clinical Aspects. In most cases, asymptomatic or mildly symptomatic pathways are promising ways for transiting DENV infection [88].

The most common signs and symptoms include pain of bone, joint, muscle, and retro-orbital; headache; fever $\left(40^{\circ} \mathrm{C}\right)$; maculopapular or macular rash; and minor hemorrhagic manifestations including purpura, malaise, ecchymosis, petechiae, epistaxis, hematuria, bleeding gums, aches or 


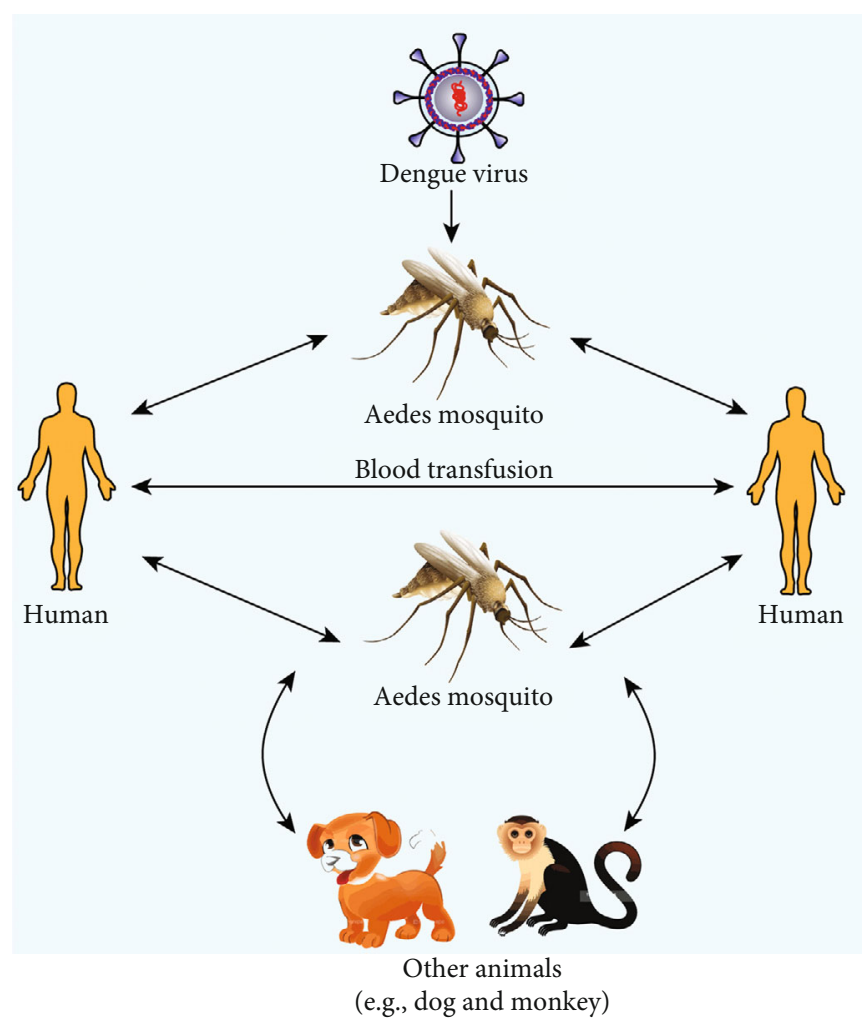

FIGURE 5: DENV transmission mode between the vector and hosts.

TABLE 1: Laboratory diagnostic approaches for DENV infection detection.

\begin{tabular}{lcc}
\hline Clinical sample & Diagnostic approach & Methodology \\
\hline $\begin{array}{l}\text { Acute serum (1-5 days of DF) and necropsy } \\
\text { tissue }\end{array}$ & $\begin{array}{c}\text { Virus isolation } \\
\text { Nucleic acid detection } \\
\text { Antigen detection }\end{array}$ & $\begin{array}{c}\text { Mosquito or mosquito cell culture inoculation } \\
\text { RT-PCR, real-time PCR }\end{array}$ \\
\hline $\begin{array}{l}\text { Paired sera } \\
\text { S1: acute serul from } 1 \text { to } 5 \text { days } \\
\text { S2: convalescent serum } 15-21 \text { days }\end{array}$ & IgG or IgM seroconversion (S1 & $\begin{array}{c}\text { NS1 Ag rapid test, NS1 Ag capture ELISA, } \\
\text { immunohistochemistry }\end{array}$ \\
\hline Serum after day 5 of DF & to S2) & ELISA \\
\end{tabular}

Abbreviations: Ag: antigen; DF: dengue fever; ELISA: enzyme-linked immunosorbent assay; HI: hemagglutination inhibition assay; IgG: immunoglobulin G; IgM: immunoglobulin M; MAC: immunoglobulin M antibody capture; NS1: non-structural protein 1; RT-PCR: reverse-transcription polymerase chain reaction.

pain, or a positive tourniquet test result. Dengue fever lasts from 3 to 7 days. Before appearing the warning signs of severe DENV infection, a slight portion of the infected patients goes to life-threatening conditions [89].

Severe DENV infection can cause organ impairment, bleeding, and plasma leakage. The warning signs during dengue infection include vomiting, abdominal pain, respiratory distress, clinical/fluid accumulation, lethargic condition, mucosal bleeding, liver enlargement $(>2 \mathrm{~cm})$, restlessness, lethargic condition, and rapid decrease in platelet count. An intensive care should be taken for the patients having infancy, pregnancy, chronic hemolytic diseases, renal failure, diabetes, obesity, and old age [2]. Chronic infections of DENV may preserve in the central nervous system and can be considered in progressive dementia patients [90].

In a recent study by Suppiah et al., the link between clinical manifestation characteristic of Dengue fever and genotypes, respectively, and DENV-specific phenotypes, was highlighted. Thus, it was found that the clinical symptoms are more severe in patients infected with DENV 2 serotype, compared to patients infected with DENV1 serotype. Musculoskeletal manifestations are characteristic of DENV 


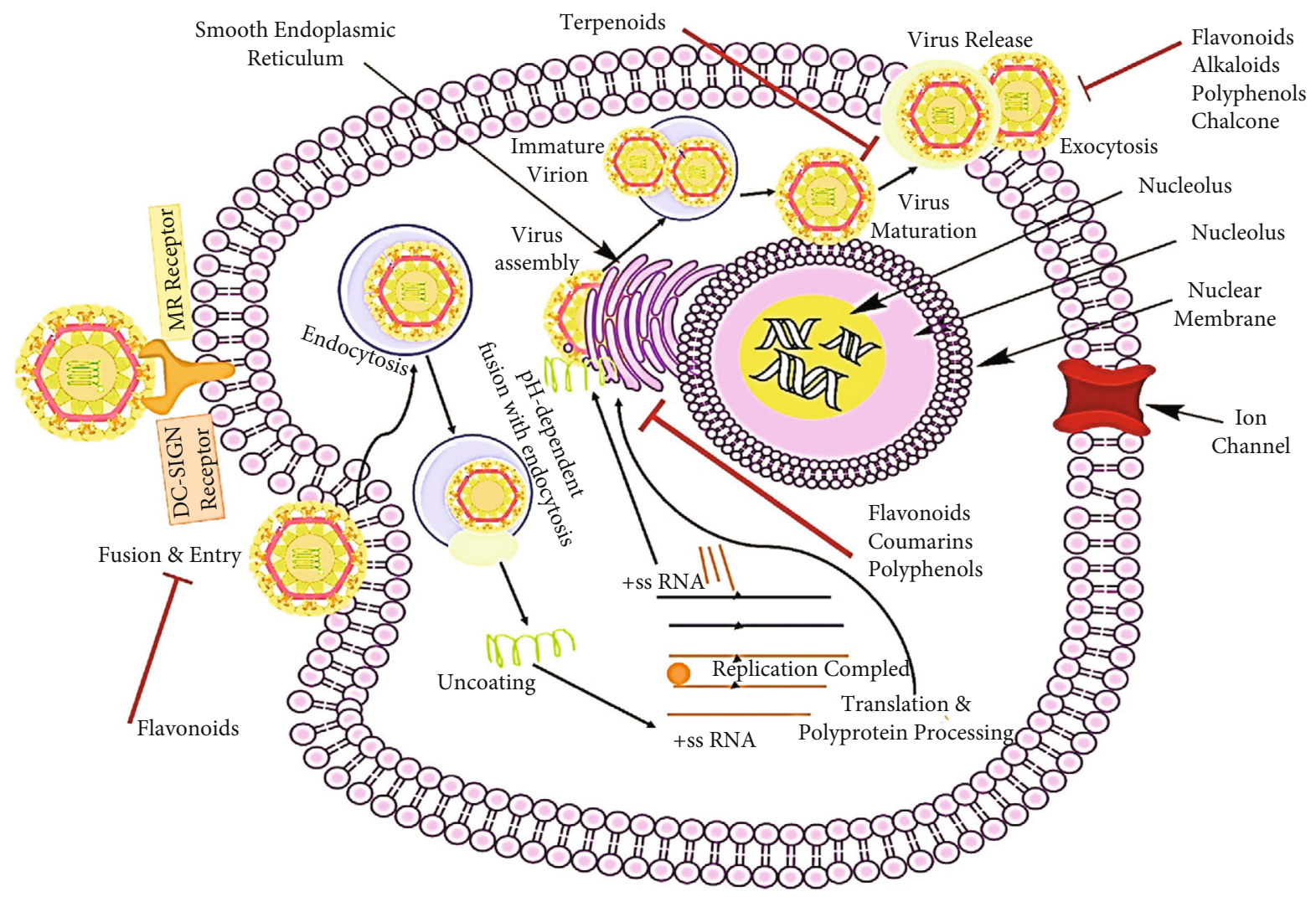

Figure 6: Potential antiviral mechanism and molecular targets of the bioactive compounds inhibiting viral entry and replication of dengue virus.

serotype 3 infection [91]. Also, nonstructural proteins (e.g., NS1, NS3, and NS5) can be targeted to develop a novel vaccine strategy $[92,93]$.

3.6. Diagnosis. Unfortunately, still, the signs and symptoms are the foremost tools for the DENV infection diagnosis $[94,95]$. Fever or flu-like fever is the initial tool of DENV infection.

To date, the well-known tests for detecting the presence of DENV include identification of the responsible viral genomic sequences, DENV serotype, viral antigen(s) (e.g., NS1 by MAC-ELISA assays) and/or antibodies in response to it (e.g., IgG, IgM), and platelet counts.

Other important diagnosis includes viral RNA detection (by nucleic acid amplification tests (NAAT) or RT-PCR), detection of dengue specific monoclonal antibodies, IgM captured ELISA, alive and/or viral isolation from mosquito cell lines [96-100]. Immune-fluorescence tests, capture ELISA, and hemagglutination assays are the commonly used laboratory methods [101]. Other test includes +ve tourniquet test, leukopenia, HCT concurrent with a rapid decrease in platelet count, AST or ALT $\geq 1000 \mathrm{IU} / \mathrm{L}$, and impaired consciousness [102]. Some important diagnostic approaches and methodology have been shown in Table 1.

\section{Control of DENV and Its Vectors}

Public awareness counts as one of the major consequences of the management of DENV, which essentially helps to avoid or inhibit the contacts of the infected Aedes mosquitoes or other animals and their derivatives [103]. In this way, Ae. aegypti was properly eradicated during the 1960s from different areas of the USA. For this, a well-educated society needs the strongest collaborative activities with skilful and well-trained mosquito control staff [104].

It is possible to control DENV infection by using different interesting methods.

4.1. Preventive Measures. Preventive measures should be the first and best choice in this case, such as the prevention of direct contact of blood or blood-derived products from the infected patients and infected vectors from the infected host [105]. Daytime is the most suitable time for biting Aedes mosquitoes; consequently, its contact can be diminished or avoided using the following techniques:

(i) By using nets (e.g., insecticide-treated nets) and mosquito repellents (e.g., coils, solids (sticks), aerosols, liquids, pump sprays, and nonsticky creams)

(ii) By wearing gloves and other defensive clothing

(iii) Through well-planed management of wastes and stored water

(iv) By destroying the mature Aedes mosquitoes or larvae through applying some protective chemicals (e.g., N,N-Diethyl-3-Methylbenzamide, diethyl carbonate, metofluthrin, oil of lemon-eucalyptus, 


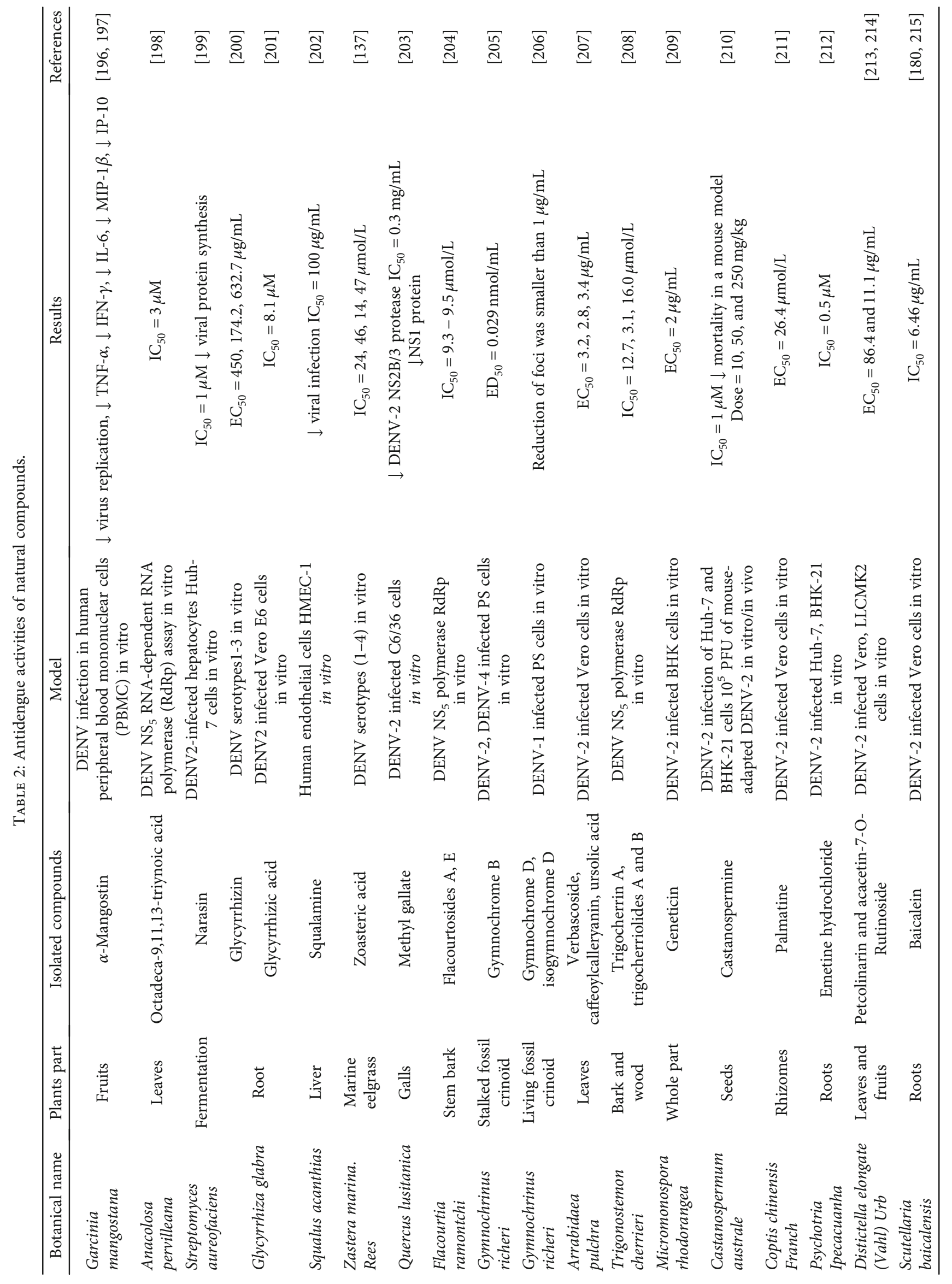




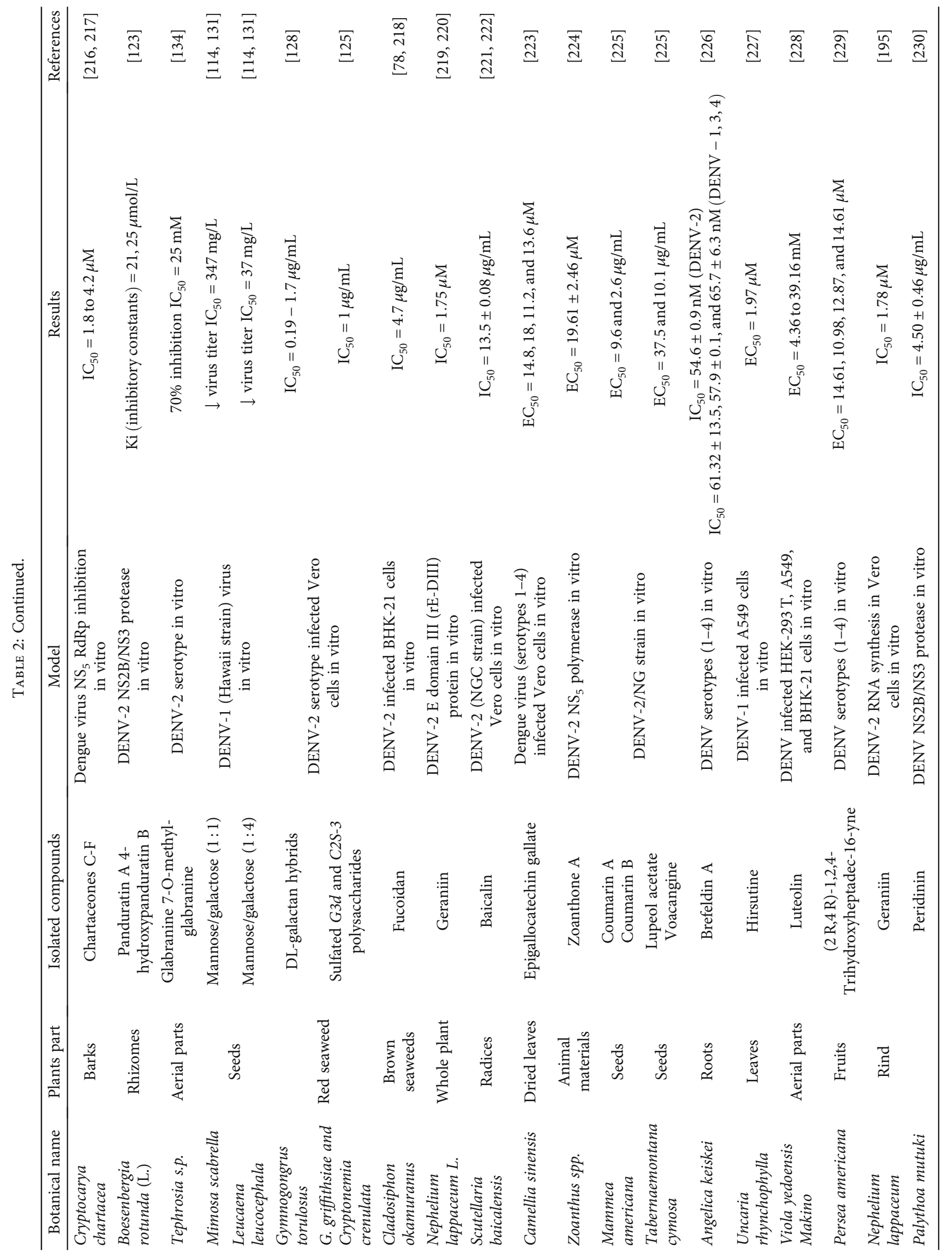




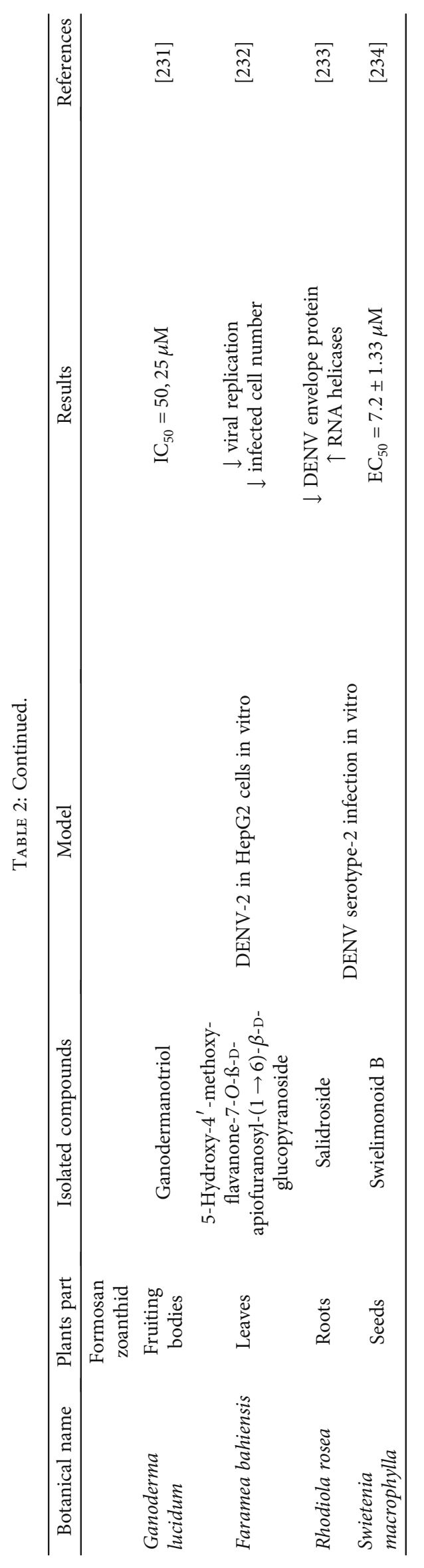




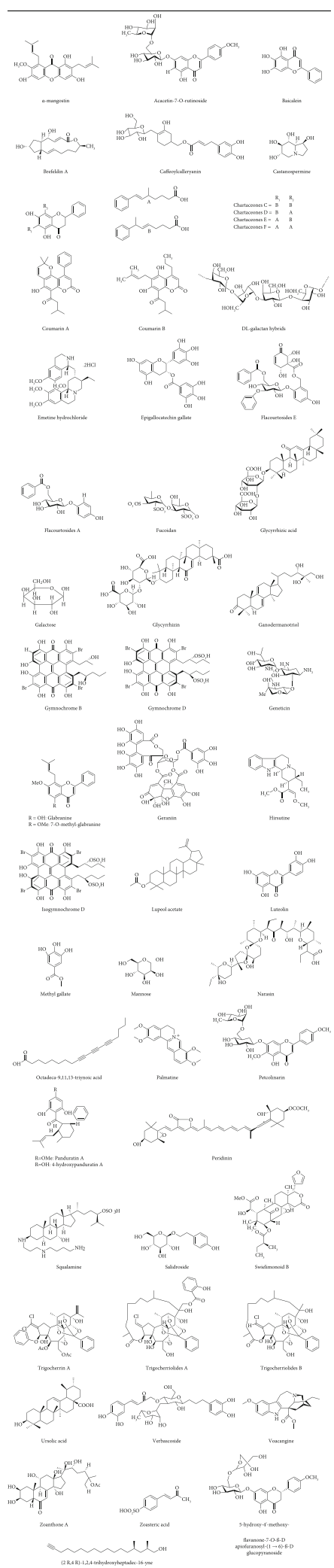

FIgURE 7: Chemical structures of natural compounds acting against dengue. 
diethyl phthalate, ethyl hexanediol, and picaridin) $[106,107]$.

CYD-TDV (brand name Dengvaxia), an one and only FDA approved live-attenuated dengue vaccine prepared by applying rDNA technology through substituting the premembrane (PrM) and envelope (E) structural proteins of the 17D strain of attenuated yellow fever vaccine with those from the dengue serotypes excepting DENV-5 serotype, is manufactured by Sanofi Pasteur [108, 109]. Other vaccines under development are DENVax/TAK-003 (recombinant chimeric vaccine with DENV-1, -3 , and -4 components on the DENV-2 backbone, developed at Mahidol University in Bangkok) $[110,111]$, TetraVax-DV (tetravalent admixture of monovalent vaccines, being tested in Brazil and Thailand in phase II trial) [112], TDEN PIV (inactivated tetravalent vaccine, being experimented by the Walter Reed Army Institute of Research and GSK in phase I clinical trials) [113], V180 (recombinant subunit vaccines expressed in Drosophila cells, undergoing phase I trial by Merck [114], and DNA vaccines (the Naval Medical Research Center attempted to develop a monovalent DNA plasmid vaccine) [111].

4.2. The Role of Natural Products and Their Bioactive Constituents in Controlling DENV Infection. Natural products are the potential sources of many important modern medicines [115-117]. Plants and/or their extracts having antidengue activities are also distributed worldwide [118-120]. To date, a number of medicinal plants have been reported to act against DENV and/or their vectors, for example, Alternanthera philoxeroides (Fam: Amaranthaceae) [121], Azidarachta indica (Fam: Meliaceae) [122], Boesenbergia rotunda (Fam: Zingiberaceae) [123], Carica papaya (Fam: Caricaceae) [124], Cladosiphon okamuranus (Fam: Chordariaceae) [78], Cryptonemia crenulata (Fam: Halymeniaceae) and Gymnogongrus griffithsiae (Fam: Phyllophoraceae) [125], Cymbopogon citratus (Fam: Poaceae), Andrographis paniculata (Fam: Acanthaceae), Momordica charantia (Fam: Cucurbitaceae), Ocimum sanctum (Fam: Labiatae), Piper retrofractum (Fam: Piperaceae) [126], Flagellaria indica (Fam: Flagellariaceae), Cladogynos orientalis (Fam: Euphorbiaceae), Rhizophora apiculata (Fam: Rhizophoraceae) and Houttuynia cordata (Fam: Saururaceae) [127], Gymnogongrus torulosus (Fam: Phyllophoraceae) [128], Lippia alba and L. citriodora (Fam: Verbenaceae) [129], Meristiella gelidium (Fam: Solieriaceae) [130], Mimosa scabrella (Fam: Fabaceae) [131], Psidium guajava (Fam: Myrtaceae) and Euphorbia hirta (Fam: Euphorbiaceae) (Abd [132]), Quercus lusitanica (Fam: Fagaceae) [133], Tephrosia crassifolia, Tephrosia madrensis, Leucaena leucocephala, and Tephrosia viridiflora (Fam: Fabaceae) [131, 134, 135], Uncaria tomentosa (Fam: Rubiaceae) [136], Zostera marina (Fam: Zosteraceae) [137], Myristica fatua, Cymbopogon citratus and Acorus calamus [138], Doratoxylum apetalum [139], Psiloxylon mauritianum [140], Acorus calamus (Fam: Acoraceae) [141], Cinnamosma fragrans [142], Pedalium murex [143], Aesculus hippocastanum [144], Norantea brasiliensis [145], Azadirachta indica [146], Spondias mombin [147], Angelica sinensis [148], Phyllanthus spp. [149], Solanum xanthocarpum, Mesocyclops thermocyclopoides (Mahesh [150]), Delonix elata (Fam: Fabaceae) [151], Acalypha alnifolia (Fam: Euphorbiaceae) [152], Combretum collinum [153], and Solanum villosum [154].

The aqueous extract of Houttuynia cordata (10-100 mg/ $\mathrm{mL}$ ) against DENV-2 with human hepatocarcinoma cell lineage (HepG2) cells showed that extract significantly decreased intracellular DENV-2 RNA production with the reduction in the expression of dengue protein. It also showed a potential role in the release of the virion from infected LLC-MK2 cells at $10-40 \mathrm{mg} / \mathrm{mL}$ concentrations [155]. $9 \mathrm{~N}$-methylamine and Harmol may selectively inhibit DENV-2 multiplication without virucidal effect in cell cultures [156].

The ethyl acetate fraction of $H$. cordata and quercetin showed in vitro activity against mouse hepatitis virus (MHV) and DENV-2 with $\mathrm{IC}_{50} 0.98$ and $125 \mu \mathrm{g} / \mathrm{mL}$ for MHV while 7.50 and $176.76 \mu \mathrm{g} / \mathrm{mL}$ for DENV-2 [157]. Delphinidin and epigallocatechin gallate showed a direct effect on against West Nile virus (WNV) and also reduced the infectivity of ZIKV and DENV. The effect of delphinidin and, particularly of epigallocatechin gallate, was found higher for the African strain (MR766) than for the American strain (PA259459) [158].

In another study, it was found an absence of anti-DENV activity in chemical constituents like acetyl-L-carnitine, melatonin, $\alpha$-tocopherol, and folic acid while resveratrol exhibited some limited anti-DENV activity [159]. Organosulfur compounds in garlic were tested against DENV-2 NGC (New Guinea C) virus U937 human macrophagelike cells and Huh-7 human liver cells. The organosulfur compounds reduced the levels of proinflammatory cytokines (TNF- $\alpha$, IL-8 and IL-10) and affect the oxidative stress response [160].

The methanol extract of Rumex dentatus showed the highest antiviral efficacy by inhibiting DENV-2 replication, with $\mathrm{IC}_{50}$ of 0.154 and $0.234 \mu \mathrm{g} / \mathrm{mL}$, while gallic acid showed with $\mathrm{IC}_{50}$ of $0.191 \mu \mathrm{g} / \mathrm{mL}$ and $0.522 \mu \mathrm{g} / \mathrm{mL}$ at 45 and $90 \mathrm{PFU}$ of DENV-2 infection, respectively [161].

Naringenin (citrus flavanone) was evaluated against dengue viruses (serotypes 1-4) in Huh7.5 cells which impaired virus replication in human cells with $\mathrm{IC}_{50}=35.81,17.97$, 117.1 , and $177.5 \mu \mathrm{M}$, respectively [162]. Annona muricata aqueous leave extract was evaluated against dengue virus type 2 . Selectivity index of the extract was found more than 10 against DENV-2 which showed potential as a naturebased antiviral drug [163]. Three spirotetronate compounds (2EPS-A, -B, -C) isolated from Actinomadura strain showed strong DENV-2 NS2B-NS3 protease inhibition with $\mathrm{IC}_{50}$ values of $1.94 \pm 0.18,1.47 \pm 0.15$, and $2.51 \pm 0.21 \mu \mathrm{g} / \mathrm{mL}$, respectively [164].

In vitro activity of essential oils of $\beta$-caryophyllene was evaluated against DENV-2. $\beta$-caryophyllene acts on the initial steps of the viral replication cycle and showed inhibition with $\mathrm{IC}_{50}=22.5 \pm 5.6 \mu \mathrm{M}$ against DENV-2 [165]. The ethanol extract of polyherbal formulation Nilavembu kudineer showed antiviral activity against DENV-2 virus infection in Vero and human macrophage cell line (THP-1 cells) from $0.78 \%$ till $0.01 \%$ of the human dose [166]. 
The aqueous leave extract of Orthosiphon stamineus was evaluated against DENV-2. The extract exhibited the ability to reduce DENV-2 replication in the pretreated cell while ineffective in inhibiting cell death in the posttreated cell [167]. Antiviral activity of natural alkaloid anisomycin was evaluated against DENV and ZIKV viruses. The compound prevented DENV and ZIKV multiplication in human cell lines, inhibited viral protein expression, and also impaired viral replication in the posttreated cell. In a lower dose, it also showed a significant decrease in viremia levels in ZIKV infected AG129 mice [168]. A natural antimicrobial agent (latarcin peptide) was evaluated against DENV replication in infected cells. The peptide exhibited a significant inhibitory effect $\left(\mathrm{IC}_{50}=12.68 \pm 3.2 \mu \mathrm{M}\right)$ against the dengue protease NS2B-NS3pro at room temperature and also reduced the viral RNA in a dose-dependent manner [169].

The crude extract of Rhodiola imbricata showed an antiviral immune response against the dengue virus. It induced interferon (IFN) $b$ and other cytokines and also upregulated MIF$2 \mathrm{a}, \mathrm{PKR}$, and NF- $\kappa \mathrm{B}$ phosphorylation in infected cells [170]. The antiviral effect of $C$. longa extract showed low cytotoxicity and effective inhibitor $\left(\mathrm{IC}_{50}=17.91 \mu \mathrm{g} / \mathrm{mL}\right)$ against DENV-2 infected Huh7it-1 cells [171]. The hydroalcoholic extracts of leaves and bark of Uncaria guinanensis DENV-2-infected Huh-7 cells reduced intracellular viral antigen and inhibited the secretion of viral nonstructural protein [172]. The chemical compound 5-hydroxy-7-methoxy-6-methylflavanone inhibited DENV2 infectivity in LLC/MK2 $\left(\mathrm{EC}_{50}=15.99 \pm 5.38\right)$ as well as Vero cell lines $\left(\mathrm{EC}_{50}=12.31 \pm 1.64 \mu \mathrm{M}\right)$ and DENV4 $\left(\mathrm{EC}_{50}=11.70 \pm 6.04 \mu \mathrm{M}\right)$. Phospholipase $\mathrm{A}_{2}$, a chemical constituent of Crotalus durissus terrificus venom, was inhibited dengue virus and yellow fever virus infection in Vero cells, inducing a partial exposure of genomic RNA through glycerophospholipids cleavage [173]. Tomatidine has inhibited dengue virus mainly at late stages of infection towards all dengue virus serotypes and controlled the activating transcription factor 4 (ATF4) expression. It showed inhibition of DENV2 $\left(\mathrm{EC}_{50}=0.82 \mu \mathrm{M}\right)$ infection mainly independent of ATF4 [174].

In silico analysis showed that Nimbin is found to be effective and reducing the morbidity and mortality against the envelope protein of DENV 1-4 infection [175]. Quinic acid derivatives were found effective against DENV1-4 and exhibited impaired dengue virus replication in infected Huh7.5 cell lines [176]. The antiviral activity of isobutyl gallate was evaluated against DENV. Isobutyl gallate exhibited no cytotoxic activity against Huh 7 and possessed strong activity $\left(\mathrm{IC}_{50}=4.45 \mu \mathrm{g} / \mathrm{mL}\right.$ against DENV [177]. Gallic acid, fisetin, quercetin, and catechin inhibited infectious viral particles production against DENV-2 infected Vero cells [178-180]. Gedunin was evaluated against the DENV infected BHK-15 cells. Gedunin showed a significant reduction $\left(\mathrm{EC}_{50}=10 \mu \mathrm{M}\right)$. In addition, the molecular docking study showed the strong interaction of the compound with the ATP/ ADP binding site of the host protein (Hsp90) [181].

The study of thrombocytopenia $(\leq 30,000 / \mu \mathrm{l})$ in adult dengue infections, leaves of Carica papaya extract, was enhanced platelet counts, $\mathrm{TNF} \alpha$, and IFN $\gamma$ levels while it reduced IL-6 levels in patients [182]. In another pilot study was done in Srilanka, two doses of leaves extract at $8 \mathrm{~h}$ of intervals were found an increase in total $\mathrm{WBC}$ and platelet count within $24 \mathrm{~h}$ of treatment [183]. The $25 \mathrm{~mL}$ leave juice of C. papaya (two times a day for 5 days) was found an increase in total WBC and platelet count after 2 days of drug administration in Pakistani patients [124].

The aqueous leave extract of $C$. papaya was tested against DENV-infected THP-1 cells and its role on platelet augmentation. The leave extract was facilitated in platelet augmentation and showed antidengue activity by a significant reduction in the envelope expression, erythrocyte damage, nonstructural (NS1) proteins, lipid peroxidation, and intracellular viral load. In addition, thrombocytopenic rats administered with aqueous extract exhibited increased IL-6 and thrombopoietin levels [184]. In Indonesia, hydroalcoholic leave extract of C. papaya was given in capsule form to the patient having a thrombocyte count of $<150,000 / \mu \mathrm{L}$ along with $20 \%$ hematocrit. The recovery of patients was found faster via speedy increase platelets levels [185].

The leave extract of Hippophae rhamnoides was tested in DENV-2 infected BHK-21 cells. The extract was found potential antidengue activity by sustaining the cell viability in infected cells, decreasing TNF- $\alpha$ and increasing IFN- $\gamma$ levels [186]. Aqueous extract of the Scutellaria baicalensis roots was tested against DENV 1-4 serotype-infected Vero cells. The extract exhibited strong virus replication property $\left(\mathrm{IC}_{50}=74.33\right.$ to $95.83 \mu \mathrm{g} / \mathrm{mL}$ for DENV $1-4$ serotypes $)$ [187]. The aqueous extract of Solanum villosum green berries showed the highest mortality against Stegomyia aegypti [154]. The silver nanoparticles (AgNPs) were synthesized from Holarrhena antidysenterica bark extract which showed strong larvicidal activity $\left(\mathrm{LC}_{50}=9.3 \mathrm{ppm}\right)$ as compared with other organic solvents and aqueous extract alone [188]. The synthesized AgNPs from Gmelina asiatica leave extracts showed potent larvicidal activity $\left(\mathrm{LC}_{50}=22.44 \mu \mathrm{g} / \mathrm{mL}\right)$ against Anopheles stephensi larvae [189].

4.3. Chemicobiological Data. Isolated compounds of medicinal plants and/or their derivatives may be one of the potential tools for the treatment of DENV and act against the vectors [190], such as essential oils [191], polyphenols [192], flavonoids [140], alkaloids [193], glycosides [194], and tannins [195].

The antiviral mechanism of natural compounds inhibiting viral entry and replication is shown in Figure 6.

Infection of virus involves various stages:

(i) In the initial steps, DENV binds to cell receptors including mannose-binding receptor (MR) and DC-SIGN (dendritic cell-specific ICAM3 grabbing nonintegrin) receptor present at the surface of the cell, followed by fusion and entry

(ii) Clathrin-mediated endocytosis and transport of DENV take place along with $\mathrm{pH}$-dependent fusion with endocytosis

(iii) The genomic ssRNA (positive-sense) is translated hooked on a polyprotein, which is smitten into all proteins 
(iv) Transcription and ribonucleic acid (RNA) replication occurs at the endoplasmic reticulum (ER) surface

(v) A synthesized dsRNA genomic virus is taking place at ER. At the ER, virions bud and are passaged to the Golgi, where DENV prM (membrane) protein is cleaved, and virion maturation takes place and is released by exocytosis

Natural compounds inhibit several proteins involved in the transcription as well as translation machinery essential in the DENV life cycle.

Furthermore, natural compounds block the virus replication by modulating the inflammatory redox-sensitive pathways and host cell signaling. Details of plant-derived natural compounds and their antidengue activities are stipulated in Table 2, and their chemical structures have been displayed in Figure 7.

Monocyte macrophages are thought to be the principal target cells for the DENV, the cause of dengue fever and hemorrhagic fever. Besides $\mathrm{Ca}^{2+}$, depletion of $\mathrm{Mg}^{2+}$ is also evident during binding of DENV to monocyte macrophages and cells of $\mathrm{T}$ cell and $\mathrm{B}$ cell lineages in in vitro studies [8]. It has been seen that the monocyte-derived macrophages discriminated in the presence of vitamin D3 restrict DENV infection and moderate the classical inflammatory cytokine (e.g., TNF- $\alpha$ and IL- $1 \beta,-4$, and -10) response, where a reduced surface expression of C-type lectins, including the mannose receptor [214].

In another report, $1,25(\mathrm{OH}) 2 \mathrm{D} 3$ is evident to suppress the levels of IL- 4 and IL-17A and modulate the levels of IL-12p70 and IL-10 in DENV infected U937-DC-SIGN cells and THP-1 macrophages, suggesting an immunomodulatory power that can ameliorate inflammation during dengue infections [196]. These findings have also complied with an earlier report [217]. In a clinical study, patients $(n=64)$, received a single dose of $200,000 \mathrm{IU}$ vitamin $\mathrm{D}$, was found to decrease the risk of dengue fever [220]. A challenge test done with 10 healthy individuals supplemented with 1000 or 4000 international units (IU)/day of vitamin D during 10 days suggested that $4000 \mathrm{IU} /$ day of vitamin $\mathrm{D}$ represents an adequate dose to control DENV progression and replication [222].

\section{Conclusions and Perspectives}

To date, it is not possible to recognize intricate details and the complexity of the target of DENV of the other suitable vectors/secondary or hosts for its entrance, production, transmission, and pathogenesis. Several preventive measures have been taken; however, still, there is a deficiency of operative treatment modalities of DENV infections in human and pet animals. DENV-mediated imbalance of micronutrients may be one of the effective significances of numerous pathophysiological situations, such as $\mathrm{Ca}^{+2}$ depletion for muscle pain, irregular heartbeats, muscle weakness, fatigue, painful signs and symptoms, and deficiency of vitamin D in case of inflammatory conditions. The deficiency of vita- min D leads to oxidative stress and the inflammatory process [235], which may contribute to lowering the standard levels of platelet in patients with DENV. The internal bleeding and fatigue of the infected patients perform the leading functions for platelet deficiency.

Taken together, the biochemical markers and immunological parameters can be considered as important diagnostic tools in DENV infection. Besides preventive measures, the medicinal plants and their derivatives might be alternative tools in the treatment of DENV infection. Calcium along with vitamin $\mathrm{D}$ supplements can be used in DENV infection. More researches are necessary regarding to the successful diagnosis, prevention, and control of dengue worldwide.

\section{Data Availability}

The data used to support the findings of this study are available from the corresponding author upon request.

\section{Conflicts of Interest}

The authors declare that they have no conflicts of interest.

\section{Acknowledgments}

This work was supported by CONICYT PIA/APOYO CCTE AFB170007.

\section{References}

[1] V. H. Ferreira-de-Lima and T. N. Lima-Camara, "Natural vertical transmission of dengue virus in Aedes aegypti and Aedes albopictus: a systematic review," Parasites \& Vectors, vol. 11, no. 1, p. 77, 2018.

[2] M. K. Zahoor, A. Rasul, M. A. Zahoor et al., Dengue fever: A general perspective. Chapter 1, IntechOpen, 2018.

[3] WHO, Dengue and Severe Dengue, World Health Organization (WHO) Report, 2019.

[4] A. Wilder-Smith, E. E. Ooi, O. Horstick, and B. Wills, "Dengue," Lancet, vol. 393, no. 10169, pp. 350-363, 2019.

[5] L. C. Katzelnick, J. M. Fonville, G. D. Gromowski et al., "Dengue viruses cluster antigenically but not as discrete serotypes," Science, vol. 349, no. 6254, pp. 1338-1343, 2015.

[6] D. Normile, "Tropical medicine. Surprising new dengue virus throws a spanner in disease control efforts," Science, vol. 342, no. 6157, p. $415,2013$.

[7] E. Holmes and S. Twiddy, "The origin, emergence and evolutionary genetics of dengue virus," Infection, Genetics and Evolution, vol. 3, no. 1, pp. 19-28, 2003.

[8] H. Bielefeldt-Ohmann, M. Meyer, D. R. Fitzpatrick, and J. S. Mackenzie, "Dengue virus binding to human leukocyte cell lines: receptor usage differs between cell types and virus strains," Virus Research, vol. 73, no. 1, pp. 81-89, 2001.

[9] I. C. dos Reis, G. Gibson, T. Ayllón et al., "Entomo-virological surveillance strategy for dengue, Zika and chikungunya arboviruses in field-caught Aedes mosquitoes in an endemic urban area of the Northeast of Brazil," Acta Tropica, vol. 197, p. 105061, 2019. 
[10] J. P. Messina, O. J. Brady, N. Golding et al., "The current and future global distribution and population at risk of dengue," Nature Microbiology, vol. 4, no. 9, pp. 1508-1515, 2019.

[11] V. P. Waman, S. M. Kasibhatla, M. M. Kale, and U. KulkarniKale, "Population genomics of dengue virus serotype 4: insights into genetic structure and evolution," Archives of Virology, vol. 161, no. 8, pp. 2133-2148, 2016.

[12] M. Castillo-Méndez and V. Valverde-Garduño, “Aedes aegypti Immune response and its potential impact on dengue virus transmission," Viral Immunology, vol. 33, no. 1, pp. 3847, 2020.

[13] A. Wilder-Smith, "The expanding geographic range of dengue in Australia," The Medical Journal of Australia, vol. 215, no. 4, pp. 171-172, 2021.

[14] N. A. Johari, K. Voon, S. Y. Toh, L. H. Sulaiman, I. K. S. Yap, and P. K. C. Lim, "Sylvatic dengue virus type 4 in Aedes aegypti and Aedes albopictus mosquitoes in an urban setting in peninsular Malaysia," PLoS Neglected Tropical Diseases, vol. 13, no. 11, article e0007889, 2019.

[15] I. M. Kramer, A. Kreß, D. Klingelhöfer et al., "Does winter cold really limit the dengue vector Aedes aegypti in Europe?," Parasites \& Vectors, vol. 13, no. 1, p. 178, 2020.

[16] R. A. Marinho, E. B. Beserra, M. A. Bezerra-Gusmão, V. D. S. Porto, R. A. Olinda, and C. A. C. Dos Santos, "Effects of temperature on the life cycle, expansion, and dispersion of Aedes aegypti (Diptera: Culicidae) in three cities in Paraiba, Brazil," Journal of Vector Ecology, vol. 41, no. 1, pp. 1-10, 2016.

[17] M. Hau, R. E. Ricklefs, M. Wikelski, K. A. Lee, and J. D. Brawn, "Corticosterone, testosterone and life-history strategies of birds," Proceedings of the Royal Society B: Biological Sciences, vol. 277, no. 1697, pp. 3203-3212, 2010.

[18] J. Gaburro, P. N. Paradkar, M. Klein, A. Bhatti, S. Nahavandi, and J. B. Duchemin, "Dengue virus infection changes Aedes aegypti oviposition olfactory preferences," Scientific Reports, vol. 8, no. 1, pp. 1-11, 2018.

[19] K. A. Hanley, T. P. Monath, S. C. Weaver, S. L. Rossi, R. L. Richman, and N. Vasilakis, "Fever versus fever: the role of host and vector susceptibility and interspecific competition in shaping the current and future distributions of the sylvatic cycles of dengue virus and yellow fever virus," Infection, Genetics and Evolution, vol. 19, pp. 292-311, 2013.

[20] A. D. Haddow, H. Guzman, V. L. Popov et al., "First isolation of Aedes flavivirus in the Western Hemisphere and evidence of vertical transmission in the mosquito Aedes (Stegomyi) albopictus (Diptera: Culicidae)," Virology, vol. 440, no. 2, pp. 134-139, 2013.

[21] S. Thongyuan and P. Kittayapong, "First evidence of dengue infection in domestic dogs living in different ecological settings in Thailand," PLoS One, vol. 12, no. 8, article e0180013, 2017.

[22] J. L. Ramirez and G. Dimopoulos, "The Toll immune signaling pathway control conserved anti-dengue defenses across diverse _Ae. aegypti_strains and against multiple dengue virus serotypes," Developmental and Comparative Immunology, vol. 34, no. 6, pp. 625-629, 2010.

[23] Z. Xi, J. L. Ramirez, and G. Dimopoulos, "The Aedes aegypti toll pathway controls dengue virus infection," PLoS Pathogens, vol. 4, no. 7, article e1000098, 2008.

[24] N. Luplertlop, P. Surasombatpattana, S. Patramool et al., "Induction of a peptide with activity against a broad spectrum of pathogens in the Aedes aegypti salivary gland, follow- ing infection with dengue virus," PLoS Pathogens, vol. 7, no. 1 , article e1001252, 2011.

[25] J. A. Souza-Neto, S. Sim, and G. Dimopoulos, "An evolutionary conserved function of the JAK-STAT pathway in antidengue defense," Proceedings of the National Academy of Sciences of the United States of America, vol. 106, no. 42, pp. 17841-17846, 2009.

[26] N. J. Caplen, Z. Zheng, B. Falgout, and R. A. Morgan, "Inhibition of viral gene expression and replication in mosquito cells by dsRNA-triggered RNA interference," Molecular Therapy, vol. 6, no. 2, pp. 243-251, 2002.

[27] M. Hussain, T. Walker, S. L. O'Neill, and S. Asgari, "Blood meal induced microRNA regulates development and immune associated genes in the Dengue mosquito vector, _Aedes aegypti_," Insect Biochemistry and Molecular Biology, vol. 43, no. 2, pp. 146-152, 2013.

[28] X. Liu, C. Guo, Y. Huang, X. Zhang, and Y. Chen, "Inhibition of porcine reproductive and respiratory syndrome virus by Cecropin D in vitro," Infection, Genetics and Evolution, vol. 34, pp. 7-16, 2015.

[29] P.-S. Yen, A. James, J. C. Li, C. H. Chen, and A. B. Failloux, "Synthetic miRNAs induce dual arboviral-resistance phenotypes in the vector mosquito Aedes aegypti," Communications Biology, vol. 1, no. 1, p. 11, 2018.

[30] P. Miesen, A. Ivens, A. H. Buck, and R. P. van Rij, "Small RNA profiling in dengue virus 2-infected Aedes Mosquito cells reveals viral piRNAs and novel host miRNAs," PLoS Neglected Tropical Diseases, vol. 10, no. 2, article e0004452, 2016.

[31] J. C. Scott, D. E. Brackney, C. L. Campbell et al., "Comparison of dengue virus type 2-specific small RNAs from RNA interference-competent and -incompetent mosquito cells," PLoS Neglected Tropical Diseases, vol. 4, no. 10, article e848, 2010.

[32] Y. Wang, B. Jin, P. Liu, J. Li, X. Chen, and J. Gu, "piRNA profiling of dengue virus type 2-infected Asian Tiger mosquito and midgut tissues," Viruses, vol. 10, no. 4, p. 213, 2018.

[33] X. Wu, H. Hong, J. Yue et al., "Inhibitory effect of small interfering RNA on dengue virus replication in mosquito cells," Virology Journal, vol. 7, no. 1, pp. 270-270, 2010.

[34] U. Palatini, P. Miesen, R. Carballar-Lejarazu et al., "Comparative genomics shows that viral integrations are abundant and express piRNAs in the arboviral vectors Aedes aegypti and Aedes albopictus," BMC Genomics, vol. 18, no. 1, p. 512, 2017.

[35] S. Sim, N. Jupatanakul, J. L. Ramirez et al., "Transcriptomic profiling of diverse Aedes aegypti strains reveals increased basal-level immune activation in dengue virus-refractory populations and identifies novel virus-vector molecular interactions," PLoS Neglected Tropical Diseases, vol. 7, no. 7, article e2295, 2013.

[36] M. M. Choy, O. M. Sessions, D. J. Gubler, and E. E. Ooi, "Production of infectious dengue virus in Aedes aegypti is dependent on the ubiquitin proteasome pathway," PLoS Neglected Tropical Diseases, vol. 9, no. 11, article e0004227, 2015.

[37] A. Troupin, B. Londono-Renteria, M. J. Conway et al., "A novel mosquito ubiquitin targets viral envelope protein for degradation and reduces virion production during dengue virus infection," Biochimica et Biophysica Acta, vol. 1860, no. 9, pp. 1898-1909, 2016.

[38] W. C. T. Black, K. E. Bennett, N. Gorrochótegui-Escalante et al., "Flavivirus Susceptibility in Aedes aegypti," Archives of Medical Research, vol. 33, no. 4, pp. 379-388, 2002. 
[39] N. Kato, C. R. Mueller, J. F. Fuchs et al., "Evaluation of the function of a type I peritrophic matrix as a physical barrier for midgut epithelium invasion by mosquito-borne pathogens in Aedes aegypti," Vector Borne and Zoonotic Diseases, vol. 8, no. 5, pp. 701-712, 2008.

[40] I. Sánchez-Vargas, J. C. Scott, B. K. Poole-Smith et al., "Dengue virus type 2 infections of Aedes aegypti are modulated by the mosquito's RNA interference pathway," PLoS Pathogens, vol. 5, no. 2, article e1000299, 2009.

[41] J. Ramos-Castañeda, C. González, M. A. Jiménez et al., "Effect of nitric oxide on dengue virus replication in $<\mathrm{i}>$ Aedes aegypti $</ \mathrm{i}>$ and $<\mathrm{i}>$ Anopheles $</ \mathrm{i}><\mathrm{i}>$ albimanus $</ \mathrm{i}>$," Intervirology, vol. 51, no. 5, pp. 335-341, 2009.

[42] J. L. Ramirez, J. Souza-Neto, R. T. Cosme et al., "Reciprocal tripartite interactions between the Aedes aegypti midgut microbiota, innate immune system and dengue virus influences vector competence," PLoS Neglected Tropical Diseases, vol. 6, no. 3, article e1561, 2012.

[43] J. L. Ramirez, S. M. Short, A. C. Bahia et al., "Chromobacterium Csp_P reduces malaria and dengue infection in vector mosquitoes and has entomopathogenic and in vitro antipathogen activities," PLoS Pathogens, vol. 10, no. 10, article e1004398, 2014.

[44] Y. I. Angleró-Rodríguez, O. A. C. Talyuli, B. J. Blumberg et al., "An Aedes aegypti-associated fungus increases susceptibility to dengue virus by modulating gut trypsin activity," eLife, vol. 6, 2017.

[45] S. Thomas, J. Verma, M. Woolfit, and S. L. O'Neill, "Wolbachia-mediated virus blocking in mosquito cells is dependent on XRN1-mediated viral RNA degradation and influenced by viral replication rate," PLoS Pathogens, vol. 14, no. 3, article e1006879, 2018.

[46] X. Pan, G. Zhou, J. Wu et al., "Wolbachia induces reactive oxygen species (ROS)-dependent activation of the toll pathway to control dengue virus in the mosquito Aedes aegypti," Proceedings of the National Academy of Sciences of the United States of America, vol. 109, no. 1, pp. E23-E31, 2012.

[47] S. Asad, R. Parry, and S. Asgari, "Upregulation of Aedes aegypti Vagol by Wolbachia and its effect on dengue virus replication," Insect Biochemistry and Molecular Biology, vol. 92, pp. 45-52, 2018.

[48] X. Xiao, Y. Liu, X. Zhang et al., "Complement-related proteins control the flavivirus infection of Aedes aegypti by inducing antimicrobial peptides," PLoS Pathogens, vol. 10, no. 4, article e1004027, 2014.

[49] E. J. Houk, J. L. Hardy, S. B. Presser, and L. D. Kramer, "Dissemination barriers for western equine encephalomyelitis virus in Culex tarsalis infected after ingestion of low viral doses," The American Journal of Tropical Medicine and Hygiene, vol. 30, no. 1, pp. 190-197, 1981.

[50] P. R. Grimstad, S. L. Paulson, and G. B. Craig Jr., "Vector competence of Aedes hendersoni (Diptera: Culicidae) for La Crosse virus and evidence of a salivary-gland escape barrier," Journal of Medical Entomology, vol. 22, no. 4, pp. 447-453, 1985.

[51] G. K. Christophides, E. Zdobnov, C. Barillas-Mury et al., "Immunity-related genes and gene families in Anopheles gambiae," Science, vol. 298, no. 5591, pp. 159-165, 2002.

[52] M. Hoshino, F. Matsuzaki, Y.-i. Nabeshima, and C. Hama, "hikaru genki, a CNS-specific gene identified by abnormal locomotion in drosophila, encodes a novel type of protein," Neuron, vol. 10, no. 3, pp. 395-407, 1993.
[53] A. B. Barletta, L. R. Alves, M. C. L. Nascimento Silva et al., "Emerging role of lipid droplets in Aedes aegypti immune response against bacteria and Dengue virus," Scientific Reports, vol. 6, no. 1, p. 19928, 2016.

[54] J. C. Molloy, U. Sommer, M. R. Viant, and S. P. Sinkins, "Wolbachia modulates lipid metabolism in Aedes albopictus Mosquito cells," Applied and Environmental Microbiology, vol. 82, no. 10, pp. 3109-3120, 2016.

[55] M. Wu, L. V. Sun, J. Vamathevan et al., "Phylogenomics of the reproductive parasite Wolbachia pipientis wMel: a streamlined genome overrun by mobile genetic elements," PLoS Biology, vol. 2, no. 3, p. E69, 2004.

[56] N. B. Tjaden, S. M. Thomas, D. Fischer, and C. Beierkuhnlein, "Extrinsic incubation period of dengue: knowledge, backlog, and applications of temperature dependence," PLoS Neglected Tropical Diseases, vol. 7, no. 6, 2013.

[57] V. Huerta, Y. Ramos, A. Yero et al., "Novel interactions of domain III from the envelope glycoprotein of dengue 2 virus with human plasma proteins," Journal of Proteomics, vol. 131, pp. 205-213, 2016.

[58] C. Cruz-Oliveira, J. M. Freire, T. M. Conceição, L. M. Higa, M. A. R. B. Castanho, and A. T. da Poian, "Receptors and routes of dengue virus entry into the host cells," FEMS Microbiology Reviews, vol. 39, no. 2, pp. 155-170, 2015.

[59] K. I. Hidari and T. Suzuki, "Dengue virus receptor," Medicine \& Health, vol. 39, 4SUPPLEMENT, pp. S37-S43, 2011.

[60] N. Nanaware, A. Banerjee, S. M. Bagchi, P. Bagchi, and A. Mukherjee, "Dengue virus infection: a tale of viral exploitations and host responses," Viruses, vol. 13, no. 10, p. 1967, 2021.

[61] Y. Mori, T. Okabayashi, T. Yamashita et al., "Nuclear localization of Japanese encephalitis virus core protein enhances viral replication," Journal of Virology, vol. 79, no. 6, pp. 3448-3458, 2005.

[62] W.-k. Oh and J. Song, "Hsp70 functions as a negative regulator of West Nile virus capsid protein through direct interaction," Biochemical and Biophysical Research Communications, vol. 347, no. 4, pp. 994-1000, 2006.

[63] R. Bhuvanakantham, M. K. Chong, and M. L. Ng, "Specific interaction of capsid protein and importin- $\alpha / \beta$ influences West Nile virus production," Biochemical and Biophysical Research Communications, vol. 389, no. 1, pp. 63-69, 2009.

[64] K. A. Hanley, J. J. Lee, J. E. Blaney Jr., B. R. Murphy, and S. S. Whitehead, "Paired charge-to-alanine mutagenesis of dengue virus type 4 NS5 generates mutants with temperature-sensitive, host range, and mouse attenuation phenotypes," Journal of Virology, vol. 76, no. 2, pp. 525-531, 2002.

[65] R. J. Kuhn, W. Zhang, M. G. Rossmann et al., "Structure of dengue virus: implications for flavivirus organization, maturation, and fusion," Cell, vol. 108, no. 5, pp. 717-725, 2002.

[66] S. Welsch, S. Miller, I. Romero-Brey et al., "Composition and three-dimensional architecture of the dengue virus replication and assembly sites," Cell Host \& Microbe, vol. 5, no. 4, pp. 365-375, 2009.

[67] E. G. Westaway, A. A. Khromykh, and J. M. Mackenzie, "Nascent Flavivirus RNA Colocalized_in Situ_ with Double-Stranded RNA in Stable Replication Complexes," Virology, vol. 258, no. 1, pp. 108-217, 1999.

[68] V. Raquin and L. Lambrechts, "Dengue virus replicates and accumulates in _Aedes aegypti_salivary glands," Virology, vol. 507, pp. 75-81, 2017. 
[69] C. V. Filomatori, M. F. Lodeiro, D. E. Alvarez, M. M. Samsa, L. Pietrasanta, and A. V. Gamarnik, "A 5' RNA element promotes dengue virus RNA synthesis on a circular genome," Genes \& Development, vol. 20, no. 16, pp. 2238-2249, 2006.

[70] S.-n. Pattanakitsakul, J. Poungsawai, R. Kanlaya, S. Sinchaikul, S.-T. Chen, and V. Thongboonkerd, "Association of Alix with late endosomal lysobisphosphatidic acid is important for dengue virus infection in human endothelial cells," Journal of Proteome Research, vol. 9, no. 9, pp. 46404648, 2010.

[71] B. Londono-Renteria, A. Troupin, M. J. Conway et al., "Dengue virus infection of Aedes aegypti requires a putative cysteine rich venom protein," PLoS Pathogens, vol. 11, no. 10, article e1005202, 2015.

[72] T. W. Scott and A. C. Morrison, "Aedes aegypti density and the risk of dengue-virus. Ecological aspects for application of genetically modified mosquitoes," FRONTIS, vol. 2, 2003.

[73] C. S. H. Teo and J. J. H. Chu, "Cellular vimentin regulates construction of dengue virus replication complexes through interaction with NS4A protein," Journal of Virology, vol. 88, no. 4, pp. 1897-1913, 2014.

[74] S. M. Eick, A. P. Dale, B. McKay et al., "Seroprevalence of dengue and Zika virus in blood donations: A systematic review," Transfusion Medicine Reviews, vol. 33, no. 1, pp. 35-42, 2019.

[75] R. Kulkarni, D. Tiraki, D. Wani, A. C. Mishra, and V. A. Arankalle, "Risk of transfusion-associated dengue: screening of blood donors from Pune, western India," Transfusion, vol. 59, no. 2, pp. 458-462, 2019.

[76] A. Guzman and R. E. Istúriz, "Update on the global spread of dengue," International Journal of Antimicrobial Agents, vol. 36, Suppl 1, pp. S40-S42, 2010.

[77] A. Goel, D. Patel, K. Lakhani et al., "Dengue fever-a dangerous foe," Journal Indian Academy of Clinical Medicine, vol. 5, pp. 247-258, 2004.

[78] K. I. P. J. Hidari, N. Takahashi, M. Arihara, M. Nagaoka, K. Morita, and T. Suzuki, "Structure and anti-dengue virus activity of sulfated polysaccharide from a marine alga," Biochemical and Biophysical Research Communications, vol. 376, no. 1, pp. 91-95, 2008.

[79] P. D. Uchil and V. Satchidanandam, "Architecture of the Flaviviral Replication Complex:" The Journal of Biological Chemistry, vol. 278, no. 27, pp. 24388-24398, 2003.

[80] I. Kurane, B. L. Innis, S. Nimmannitya, A. Nisalak, F. A. Ennis, and A. Meager, "High levels of interferon alpha in the sera of children with dengue virus infection," The American Journal of Tropical Medicine and Hygiene, vol. 48, no. 2, pp. 222-229, 1993.

[81] I. Kurane, B. L. Innis, S. Nimmannitya et al., "Activation of T lymphocytes in dengue virus infections. High levels of soluble interleukin 2 receptor, soluble CD4, soluble CD8, interleukin 2 , and interferon-gamma in sera of children with dengue," The Journal of Clinical Investigation, vol. 88, no. 5, pp. 1473-1480, 1991.

[82] M. C. Shivanthan and S. Rajapakse, "Dengue and calcium," International Journal of Critical Illness and Injury Science, vol. 4, no. 4, pp. 314-316, 2014.

[83] G. P. Zaloga and B. Chernow, "The multifactorial basis for hypocalcemia during sepsis. Studies of the parathyroid hormone-vitamin D axis," Annals of Internal Medicine, vol. 107, no. 1, pp. 36-41, 1987.
[84] R. Bravo, V. Parra, D. Gatica et al., "Chapter Five - Endoplasmic Reticulum and the Unfolded Protein Response: Dynamics and Metabolic Integration," in International Review of Cell and Molecular Biology, K. W. Jeon, Ed., Academic Press, 2013.

[85] N. Meng, X. Ren, G. Santagiuliana et al., "Ultrahigh $\beta$-phase content poly(vinylidene fluoride) with relaxor-like ferroelectricity for high energy density capacitors," Nature Communications, vol. 10, no. 1, pp. 1-9, 2019.

[86] P. Bautista-Carbajal, R. Soto-Acosta, A. H. Angel-Ambrocio et al., "The calmodulin antagonist W-7 (N-(6-aminohexyl)5-chloro-1-naphthalenesulfonamide hydrochloride) inhibits DENV infection in Huh-7 cells," Virology, vol. 501, pp. 188-198, 2017.

[87] J. Li, R. Huang, W. Liao, Z. Chen, S. Zhang, and R. Huang, "Dengue virus utilizes calcium modulating cyclophilinbinding ligand to subvert apoptosis," Biochemical and Biophysical Research Communications, vol. 418, no. 4, pp. 622627, 2012.

[88] R. George and L. Lum, Clinical Spectrum of Dengue Infection. Dengue and Dengue Haemorrhagic Fever, CAB International, New York, 1997.

[89] I.-K. Lee, J.-W. Liu, and K. D. Yang, "Fatal dengue hemorrhagic fever in adults: emphasizing the evolutionary prefatal clinical and laboratory manifestations," PLoS Neglected Tropical Diseases, vol. 6, no. 2, article e1532, 2012.

[90] T. P. Johnson, H. B. Larman, M.-. H. Lee et al., "Chronic dengue virus panencephalitis in a patient with progressive dementia with extrapyramidal features," Annals of Neurology, vol. 86, no. 5, pp. 695-703, 2019.

[91] J. Suppiah, S.-M. Ching, S. Amin-Nordin et al., "Clinical manifestations of dengue in relation to dengue serotype and genotype in Malaysia: A retrospective observational study," PLoS Neglected Tropical Diseases, vol. 12, no. 9, p. e0006817, 2018.

[92] F. Giovannoni, M. F. Ladelfa, M. Monte, D. A. Jans, P. Hemmerich, and C. García, "Dengue non-structural protein 5 polymerase complexes with promyelocytic leukemia protein (PML) isoforms III and IV to disrupt PML-nuclear bodies in infected cells," Frontiers in Cellular and Infection Microbiology, vol. 9, pp. 284-284, 2019.

[93] Y.-S. Kao, C.-Y. Yu, H.-J. Huang et al., "Combination of modified NS1 and NS3 as a novel vaccine strategy against dengue virus infection," Journal of Immunology, vol. 203, no. 7, pp. 1909-1917, 2019.

[94] D. S. Burke, R. M. N. Scott, D. E. Johnson, and A. Nisalak, "A prospective study of dengue infections in Bangkok," The American Journal of Tropical Medicine and Hygiene, vol. 38, no. 1, pp. 172-180, 1988.

[95] T. P. Endy, S. Chunsuttiwat, A. Nisalak et al., "Epidemiology of inapparent and symptomatic acute dengue virus infection: a prospective study of primary school children in Kamphaeng Phet, Thailand," American Journal of Epidemiology, vol. 156, no. 1, pp. 40-51, 2002.

[96] S. Datta and C. Wattal, "Dengue NS1 antigen detection: a useful tool in early diagnosis of dengue virus infection," Indian Journal of Medical Microbiology, vol. 28, no. 2, pp. 107-110, 2010.

[97] P. Dussart, B. Labeau, G.. Lagathu et al., "Evaluation of an enzyme immunoassay for detection of dengue virus NS1 antigen in human serum," Clinical and Vaccine Immunology, vol. 13, no. 11, pp. 1185-1189, 2006. 
[98] A. Khan, "Frequency and clinical presentation of dengue fever at tertiary Care Hospital of Hyderabad/Jamshoro," Journal of the Liaquat University of Medical and Health Sciences, vol. 9, pp. 88-94, 2010.

[99] D. H. Libraty, P. R. Young, D. Pickering et al., "High circulating levels of the dengue virus nonstructural protein NS1 early in dengue illness correlate with the development of dengue hemorrhagic fever," The Journal of Infectious Diseases, vol. 186, no. 8, pp. 1165-1168, 2002.

[100] P.-Y. Shu, L.-K. Chen, S.-F. Chang et al., "Comparison of capture immunoglobulin $\mathrm{M}$ (IgM) and IgG enzyme-linked immunosorbent assay (ELISA) and nonstructural protein NS1 serotype-specific IgG ELISA for differentiation of primary and secondary dengue virus infections," Clinical and Diagnostic Laboratory Immunology, vol. 10, no. 4, pp. 622630, 2003.

[101] N. Butt, A. Abbassi, S. M. Munir, S. M. Ahmad, and Q. H. Sheikh, "Haematological and biochemical indicators for the early diagnosis of dengue viral infection," Journal of the College of Physicians and Surgeons-Pakistan, vol. 18, no. 5, pp. 282-285, 2008.

[102] D. A. Muller, A. C. I. Depelsenaire, and P. R. Young, "Clinical and laboratory diagnosis of dengue virus infection," The Journal of Infectious Diseases, vol. 215, suppl_2, pp. S89-s95, 2017.

[103] A. Wilder-Smith, "Dengue vaccine development by the year 2020: challenges and prospects," Current Opinion in Virology, vol. 43, pp. 71-78, 2020.

[104] N. G. Gratz, "Critical review of the vector status of Aedes albopictus," Medical and Veterinary Entomology, vol. 18, no. 3, pp. 215-227, 2004.

[105] A. Wilder-Smith, "Dengue vaccine development: status and future," Bundesgesundheitsblatt - Gesundheitsforschung Gesundheitsschutz, vol. 63, no. 1, pp. 40-44, 2020.

[106] G. Clark and M. F. Suárez, "Mosquito vector control and biology in Latin America-a second symposium," Journal of the American Mosquito Control Association, vol. 8, no. 3, pp. 305-317, 1992.

[107] N. C. Tan and S. Ho, "Treat-to-target approach in managing modifiable risk factors of patients with coronary heart disease in primary care in Singapore: what are the issues?," Asia Pacific Family Medicine, vol. 10, no. 1, p. 12, 2011.

[108] U. Thisyakorn and C. Thisyakorn, "Latest developments and future directions in dengue vaccines," Therapeutic Advances in Vaccines, vol. 2, no. 1, pp. 3-9, 2014.

[109] L. E. Yauch and S. Shresta, "Dengue virus vaccine development," Advances in Virus Research, vol. 88, pp. 315-372, 2014.

[110] J. E. Osorio, C. Y.-H. Huang, R. M. Kinney, and D. T. Stinchcomb, "Development of DENVax: a chimeric dengue-2 PDK53-based tetravalent vaccine for protection against dengue fever," Vaccine, vol. 29, no. 42, pp. 7251-7260, 2011.

[111] L. M. Schwartz, M. E. Halloran, A. P. Durbin, and I. M. Longini, "The dengue vaccine pipeline: implications for the future of dengue control," Vaccine, vol. 33, no. 29, pp. 3293-3298, 2015.

[112] S. Swaminathan and N. Khanna, "Dengue vaccine development: global and Indian scenarios," International Journal of Infectious Diseases, vol. 84, pp. S80-S86, 2019.

[113] M. A. McArthur, M. B. Sztein, and R. Edelman, "Dengue vaccines: recent developments, ongoing challenges and current candidates," Expert Review of Vaccines, vol. 12, no. 8, pp. 933-953, 2013.

[114] N. K. Tripathi and A. Shrivastava, "Recent developments in recombinant protein-based dengue vaccines," Frontiers in Immunology, vol. 9, 2018.

[115] J. Sharifi-Rad, S. Kamiloglu, B. Yeskaliyeva et al., "Pharmacological activities of psoralidin: a comprehensive review of the molecular mechanisms of action," Frontiers in Pharmacology, vol. 11, 2020.

[116] J. Sharifi-Rad, C. Quispe, J. Herrera-Bravo et al., “A pharmacological perspective on plant-derived bioactive molecules for epilepsy," Neurochemical Research, vol. 46, no. 9, pp. 22052225, 2021.

[117] D. Tsoukalas, O. Zlatian, M. Mitroi et al., "A novel nutraceutical formulation can improve motor activity and decrease the stress level in a murine model of middle-age animals," Journal of Clinical Medicine, vol. 10, no. 4, p. 624, 2021.

[118] B. Salehi, A. Rescigno, T. Dettori et al., "Avocado-soybean unsaponifiables: a panoply of potentialities to be exploited," Biomolecules, vol. 10, no. 1, p. 130, 2020.

[119] B. Salehi, M. S. Shetty, N. V. Anil Kumar et al., "Veronica plants-drifting from farm to traditional healing, food application, and phytopharmacology," Molecules, vol. 24, no. 13, p. $2454,2019$.

[120] T. A. Sani, "Cytotoxic and APOPTOGENIC properties of DRACOCEPHALUM KOTSCHYI aerial part different fractions on CALU-6 and MEHR-80 lung cancer cell lines," Farmácia, vol. 65, pp. 189-199, 2017.

[121] W. L. Jiang, X. L. Luo, and S. J. Kuang, "Effects of Alternanthera philoxeroides Griseb against dengue virus in vitro," Di Yi Jun Yi Da Xue Xue Bao, vol. 25, no. 4, pp. 454-456, 2005.

[122] M. M. Parida, C. Upadhyay, G. Pandya, and A. M. Jana, "Inhibitory potential of neem (Azadirachta indica Juss) leaves on Dengue virus type-2 replication," Journal of Ethnopharmacology, vol. 79, no. 2, pp. 273-278, 2002.

[123] T. S. Kiat, R. Pippen, R. Yusof, H. Ibrahim, N. Khalid, and N. A. Rahman, "Inhibitory activity of cyclohexenyl chalcone derivatives and flavonoids of fingerroot, _Boesenbergia rotunda_(L.), towards dengue-2 virus NS3 protease," Bioorganic \& Medicinal Chemistry Letters, vol. 16, no. 12, pp. 3337-3340, 2006.

[124] N. Ahmad, H. Fazal, M. Ayaz, B. H. Abbasi, I. Mohammad, and L. Fazal, "Dengue fever treatment with Carica papaya leaves extracts," Asian Pacific Journal of Tropical Biomedicine, vol. 1, no. 4, pp. 330-333, 2011.

[125] L. Talarico, C. Pujol, R. Zibetti et al., "The antiviral activity of sulfated polysaccharides against dengue virus is dependent on virus serotype and host cell," Antiviral Research, vol. 66, no. 2-3, pp. 103-110, 2005.

[126] L. I. C. Tang, A. P. K. Ling, R. Y. Koh, S. M. Chye, and K. G. L. Voon, "Screening of anti-dengue activity in methanolic extracts of medicinal plants," BMC Complementary and Alternative Medicine, vol. 12, no. 1, 2012.

[127] N. Klawikkan, "Effect of Thai medicinal plant extracts against dengue virus in vitro," MU J Pharm, vol. 38, pp. 13-18, 2011.

[128] C. A. Pujol, J. M. Estevez, M. J. Carlucci, M. Ciancia, A. S. Cerezo, and E. B. Damonte, "Novel DL-galactan hybrids from the red seaweed Gymnogongrus torulosus are potent inhibitors of herpes simplex virus and dengue virus," Antiviral Chemistry \& Chemotherapy, vol. 13, no. 2, pp. 83-89, 2002. 
[129] R. M. Lopez, R. E. Ocazionez, J. R. Martinez, and E. E. Stashenko, "Inhibitory effect of essential oils obtained from plants grown in Colombia on yellow fever virus replication in vitro," Annals of Clinical Microbiology and Antimicrobials, vol. 8, no. 1, pp. 8-8, 2009.

[130] P. C. De Sf-Tischer, L. B. Talarico, M. D. Noseda, S. M. Guimarães, E. B. Damonte, and M. E. Duarte, "Chemical structure and antiviral activity of carrageenans from Meristiella gelidium against herpes simplex and dengue virus," Carbohydrate Polymers, vol. 63, pp. 459-465, 2006.

[131] L. Ono, W. Wollinger, I. M. Rocco, T. L. M. Coimbra, P. A. J. Gorin, and M.-R. Sierakowski, "In vitro and in vivo antiviral properties of sulfated galactomannans against yellow fever virus (BeH111 strain) and dengue 1 virus (Hawaii strain)," Antiviral Research, vol. 60, no. 3, pp. 201-208, 2003.

[132] S. L. A. Kadir, H. Yaakob, and R. M. Zulkifli, "Potential antidengue medicinal plants: a review," Journal of Natural Medicines, vol. 67, no. 4, pp. 677-689, 2013.

[133] S. Y. Muliawan, L. S. Kit, S. Devi, O. Hashim, and R. Yusof, "Inhibitory potential of Quercus lusitanica extract on dengue virus type 2 replication," The Southeast Asian Journal of Tropical Medicine and Public Health, vol. 37, Suppl 3, pp. 132-135, 2006.

[134] I. Sánchez, F. Gómez-Garibay, J. Taboada, and B. H. Ruiz, "Antiviral effect of flavonoids on the dengue virus," Phytotherapy Research, vol. 14, no. 2, pp. 89-92, 2000.

[135] M. Srivastava and V. P. Kapoor, "Seed galactomannans: an overview," Chemistry \& Biodiversity, vol. 2, pp. 295-317, 2005.

[136] S. R. I. N. Reis, L. M. M. Valente, A. L. Sampaio et al., "Immunomodulating and antiviral activities of _Uncaria tomentosa_ on human monocytes infected with Dengue Virus-2," International Immunopharmacology, vol. 8, no. 3, pp. 468476, 2008.

[137] C. Rees, J. Costin, R. Fink et al., "In vitro inhibition of dengue virus entry by _ $\mathrm{p}_{-}$-sulfoxy-cinnamic acid and structurally related combinatorial chemistries," Antiviral Research, vol. 80, no. 2, pp. 135-142, 2008.

[138] R. Rosmalena, B. Elya, B. E. Dewi et al., "The Antiviral Effect of Indonesian Medicinal Plant Extracts against Dengue Virus In Vitro and in Silico," Pathogens, vol. 8, no. 2, p. 85, 2019.

[139] J. G. Haddad, A. C. Koishi, A. Gaudry et al., "Doratoxylon apetalum, an indigenous medicinal plant from Mascarene Islands, is a potent inhibitor of Zika and dengue virus infection in human cells," International Journal of Molecular Sciences, vol. 20, no. 10, p. 2382, 2019.

[140] E. Clain, J. G. Haddad, A. C. Koishi et al., “The polyphenolrich extract from Psiloxylon mauritianum, an endemic medicinal plant from Reunion Island, inhibits the early stages of dengue and Zika virus infection," International Journal of Molecular Sciences, vol. 20, no. 8, p. 1860, 2019.

[141] X. Yao, Y. Ling, S. Guo et al., "Tatanan A from the _Acorus calamus $L_{\text {_. }}$ root inhibited dengue virus proliferation and infections," Phytomedicine, vol. 42, pp. 258-267, 2018.

[142] E. A. Inocente, M. Shaya, N. Acosta, L. H. Rakotondraibe, and P. M. Piermarini, "A natural agonist of mosquito TRPA1 from the medicinal plant Cinnamosma fragrans that is toxic, antifeedant, and repellent to the yellow fever mosquito Aedes aegypti," PLoS Neglected Tropical Diseases, vol. 12, no. 2, article e0006265, 2018.

[143] R. Ishwarya, B. Vaseeharan, R. Anuradha et al., "Eco-friendly fabrication of Ag nanostructures using the seed extract of
_Pedalium murex_, an ancient Indian medicinal plant: Histopathological effects on the Zika virus vector_Aedes aegypti_and inhibition of biofilm- forming pathogenic bacteria," Journal of Photochemistry and Photobiology. B, vol. 174, pp. 133-143, 2017.

[144] F. M. Salinas, L. Vázquez, M. V. Gentilini et al., “Aesculus hippocastanum_ L. seed extract shows virucidal and antiviral activities against respiratory syncytial virus (RSV) and reduces lung inflammation_in vivo," Antiviral Research, vol. 164, pp. 1-11, 2019.

[145] L. G. Fialho, V. P. da Silva, S. R. N. I. Reis et al., “Antiviral and Immunomodulatory Effects of Norantea brasiliensis Choisy on Dengue Virus-2," Intervirology, vol. 59, no. 4, pp. 217227, 2017.

[146] V. D. Dwivedi, I. P. Tripathi, and S. K. Mishra, "In silico evaluation of inhibitory potential of triterpenoids from Azadirachta indica against therapeutic target of dengue virus, NS2B-NS3 protease," Journal of Vector Borne Diseases, vol. 53, no. 2, pp. 156-161, 2016.

[147] E. E. Ajaegbu, S. P. Danga, I. U. Chijoke, and F. B. Okoye, "Mosquito adulticidal activity of the leaf extracts of Spondias mombin L. against Aedes aegypti L. and isolation of active principles," Journal of Vector Borne Diseases, vol. 53, no. 1, pp. 17-22, 2016.

[148] D. Champakaew, A. Junkum, U. Chaithong et al., "Angelica sinensis (Umbelliferae) with proven repellent properties against Aedes aegypti, the primary dengue fever vector in Thailand," Parasitology Research, vol. 114, no. 6, pp. 21872198, 2015.

[149] S. H. Lee, Y. Q. Tang, A. Rathkrishnan et al., "Effects of cocktail of four local Malaysian medicinal plants (Phyllanthus spp.) against dengue virus 2," BMC Complementary and Alternative Medicine, vol. 13, no. 1, 2013.

[150] P. M. Kumar, K. Murugan, K. Kovendan et al., "Mosquitocidal activity of solanum xanthocarpum fruit extract and copepod Mesocyclops thermocyclopoides for the control of dengue vector Aedes aegypti," Parasitology Research, vol. 111, no. 2, pp. 609-618, 2012.

[151] G. Marimuthu, S. Rajamohan, R. Mohan, and Y. Krishnamoorthy, "Larvicidal and ovicidal properties of leaf and seed extracts of Delonix elata (L.) gamble (family: Fabaceae) against malaria (Anopheles stephensi Liston) and dengue (Aedes aegypti Linn.) (Diptera: Culicidae) vector mosquitoes," Parasitology Research, vol. 111, no. 1, pp. 6577, 2012.

[152] K. Kovendan, K. Murugan, and S. Vincent, "Evaluation of larvicidal activity of Acalypha alnifolia Klein ex Willd. (Euphorbiaceae) leaf extract against the malarial vector, Anopheles stephensi, dengue vector, Aedes aegypti and Bancroftian filariasis vector, Culex quinquefasciatus (Diptera: Culicidae)," Parasitology Research, vol. 110, no. 2, pp. 571581, 2012.

[153] J. Odda, S. Kristensen, J. Kabasa, and P. Waako, "Larvicidal activity of Combretum collinum Fresen against Aedes aegypti," Journal of Vector Borne Diseases, vol. 45, no. 4, pp. 321-324, 2008.

[154] N. Chowdhury, A. Ghosh, and G. Chandra, "Mosquito Larvicidal Activities Of Solanum Villosum Berry Extract Against The Dengue Vector Stegomyia Aegypti," Bmc Complementary And Alternative Medicine, vol. 8, no. 1, p. 10, 2008.

[155] V. Leardkamolkarn, W. Sirigulpanit, C. Phurimsak, S. Kumkate, L. Himakoun, and B. Sripanidkulchai, "The 
inhibitory actions of houttuynia cordata aqueous extract on dengue virus and dengue-infected cells," Journal of Food Biochemistry, vol. 36, no. 1, pp. 86-92, 2012.

[156] V. M. Quintana, L. E. Piccini, J. D. Panozzo Zénere, E. B. Damonte, M. A. Ponce, and V. Castilla, "Antiviral activity of natural and synthetic $\beta$-carbolines against dengue virus," Antiviral Research, vol. 134, pp. 26-33, 2016.

[157] K. H. Chiow, M. C. Phoon, T. Putti, B. K. H. Tan, and V. T. Chow, "Evaluation of antiviral activities of Houttuynia cordata Thunb. extract, quercetin, quercetrin and cinanserin on murine coronavirus and dengue virus infection," Asian Pacific Journal of Tropical Medicine, vol. 9, no. 1, pp. 1-7, 2016.

[158] Á. Vázquez-Calvo, N. Jiménez de Oya, M. A. Martín-Acebes, E. Garcia-Moruno, and J. C. Saiz, "Antiviral properties of the natural polyphenols delphinidin and epigallocatechin gallate against the Flaviviruses West Nile virus, Zika virus, and dengue virus," Frontiers in Microbiology, vol. 8, pp. 1314-1314, 2017.

[159] A. Paemanee, A. Hitakarun, S. Roytrakul, and D. R. Smith, "Screening of melatonin, $\alpha$-tocopherol, folic acid, acetyl-Lcarnitine and resveratrol for anti-dengue 2 virus activity," BMC Research Notes, vol. 11, no. 1, p. 307, 2018.

[160] A. Hall, A. Troupin, B. Londono-Renteria, and T. Colpitts, "Garlic organosulfur compounds reduce inflammation and oxidative stress during dengue virus infection," Viruses, vol. 9, no. 7, p. 159, 2017.

[161] R. Batool, E. Aziz, T. Mahmood, B. K. H. Tan, and V. T. K. Chow, "Inhibitory activities of extracts ofRumex dentatus, Commelina benghalensis, Ajuga bracteosa, Ziziphus mauritianaas well as their compounds of gallic acid and emodin against dengue virus," Asian Pacific Journal of Tropical Medicine, vol. 11, no. 4, p. 265, 2018.

[162] S. Frabasile, A. C. Koishi, D. Kuczera et al., "The citrus flavanone naringenin impairs dengue virus replication in human cells," Scientific Reports, vol. 7, no. 1, pp. 41864-41864, 2017.

[163] N. Z. Wahab, N. Ibrahim, M. K. Kamarudin et al., "Cytotoxicity and antiviral activity of Annona muricata aqueous leaves extract against dengue virus type 2," Journal of Fundamental and Applied Sciences, vol. 10, pp. 580-589, 2018.

[164] J. Euanorasetr, B. Intra, N. Thunmrongsiri et al., "In vitro antiviral activity of spirotetronate compounds against dengue virus serotype 2," The Journal of General and Applied Microbiology, vol. 65, no. 4, pp. 197-203, 2019.

[165] N. P. Castro, M. C. Flechas, R. Ocazionez, E. Stashenko, and J. Olivero-Verbel, "Potential interaction of components from essential oils with dengue virus proteins," Boletin Latinoamericano y del Caribe de Plantas Medicinales y Aromaticas, vol. 14, pp. 141-155, 2015.

[166] J. Jain, A. Kumar, V. Narayanan et al., "Antiviral activity of ethanolic extract of _Nilavembu Kudineer_ against dengue and chikungunya virus through_in vitro_evaluation," Journal of Ayurveda and Integrative Medicine, vol. 11, no. 3, pp. 329-335, 2020.

[167] N. Z. Wahab, N. Ibrahim, M. K. Kamarudin, F. Lananan, H. Juahir, and A. Ghazali, "In vitro antiviral activity of Orthosiphon stamineus extract against dengue virus type 2," Journal of Fundamental and Applied Sciences, vol. 10, pp. 541-551, 2018.

[168] V. M. Quintana, B. Selisko, J. E. Brunetti et al., "Antiviral activity of the natural alkaloid anisomycin against dengue and Zika viruses," Antiviral Research, vol. 176, p. 104749, 2020.

[169] H. A. Rothan, H. Bahrani, N. Rahman, and R. Yusof, "Identification of natural antimicrobial agents to treat dengue infection: in vitro analysis of latarcin peptide activity against dengue virus," BMC Microbiology, vol. 14, no. 1, p. 140, 2014.

[170] D. Diwaker, K. P. Mishra, L. Ganju, and S. B. Singh, "Rhodiola inhibits dengue virus multiplication by inducing innate immune response genes RIG-I, MDA5 and ISG in human monocytes," Archives of Virology, vol. 159, no. 8, pp. 19751986, 2014.

[171] M. Ichsyani, A. Ridhanya, M. Risanti et al., "Antiviral effects ofCurcuma longaL. against dengue virus In Vitro and In Vivo," IOP Conference Series: Earth and Environmental Science, vol. 101, p. 012005, 2017.

[172] C. da Silva Mello, L. M. M. Valente, T. Wolff et al., "Decrease in dengue virus-2 infection and reduction of cytokine/chemokine production by Uncaria guianensis in human hepatocyte cell line Huh-7," Memórias do Instituto Oswaldo Cruz, vol. 112, no. 6, pp. 458-468, 2017.

[173] V. D. Muller, R. O. Soares, N. N. dos Santos-Junior et al., "Phospholipase A2 isolated from the venom of Crotalus durissus terrificus inactivates dengue virus and other enveloped viruses by disrupting the viral envelope," PLoS One, vol. 9, no. 11, article e112351, 2014.

[174] M. Diosa-Toro, B. Troost, D. van de Pol et al., "Tomatidine, a novel antiviral compound towards dengue virus," Antiviral Research, vol. 161, pp. 90-99, 2019.

[175] P. Lavanya, S. Ramaiah, and A. Anbarasu, "Computational analysis reveal inhibitory action of nimbin against dengue viral envelope protein," Virus, vol. 26, no. 4, pp. 243-254, 2015.

[176] P. R. Zanello, A. C. Koishi, C. . O. Rezende Júnior et al., "Quinic acid derivatives inhibit dengue virus replication in vitro," Virology Journal, vol. 12, no. 1, p. 223, 2015.

[177] B. E. Dewi, M. Angelina, F. Nuwwaaridya, H. Desti, and T. M. Sudiro, "Antiviral activity of isobutyl gallate to dengue virus serotype 2In vitro," IOP Conference Series: Earth and Environmental Science, vol. 251, p. 012018, 2019.

[178] A. I. Trujillo-Correa, D. C. Quintero-Gil, F. Diaz-Castillo, W. Quiñones, S. M. Robledo, and M. Martinez-Gutierrez, "In vitro and in silico anti-dengue activity of compounds obtained from Psidium guajava through bioprospecting," BMC Complementary and Alternative Medicine, vol. 19, no. 1, p. 298, 2019.

[179] K. Zandi, B. T. Teoh, S. S. Sam, P. F. Wong, M. R. Mustafa, and S. AbuBakar, "Antiviral activity of four types of bioflavonoid against dengue virus type-2," Virology Journal, vol. 8, no. 1, p. 560, 2011.

[180] K. Zandi, B. T. Teoh, S. S. Sam, P. F. Wong, M. R. Mustafa, and S. Abubakar, "Novel antiviral activity of baicalein against dengue virus," BMC Complementary and Alternative Medicine, vol. 12, no. 1, p. 214, 2012.

[181] D. Amraiz, N. U. S. S. Zaidi, and M. Fatima, "Antiviral evaluation of an Hsp90 inhibitor, gedunin, against dengue virus," Tropical Journal of Pharmaceutical Research, vol. 16, no. 5, pp. 997-1004, 2017.

[182] D. T. Sathyapalan, A. Padmanabhan, M. Moni et al., "Efficacy \& safety of Carica papaya leaf extract (CPLE) in severe thrombocytopenia $(\leq 30,000 / \mu \mathrm{l})$ in adult dengue - results of a pilot study," PLoS One, vol. 15, no. 2, pp. e0228699e0228699, 2020. 
[183] S. Hettige, "Salutary effects of Carica papaya leaf extract in dengue fever patients a pilot study," Sri Lankan Fam Physician, vol. 29, pp. 17-19, 2008.

[184] N. Sharma, K. P. Mishra, S. Chanda et al., "Evaluation of antidengue activity of Carica papaya aqueous leaf extract and its role in platelet augmentation," Archives of Virology, vol. 164, no. 4, pp. 1095-1110, 2019.

[185] F. Yunita, E. Hanani, and J. Kristianto, "The effect of Carica papaya $\mathrm{L}$ leaves extract capsule on platelet count and hematocrit level in dengue fever patient," International Journal of Medicinal and Aromatic Plants, vol. 2, pp. 573-578, 2012.

[186] M. Jain, L. Ganju, A. Katiyal et al., "Effect of _Hippophae rhamnoides_ leaf extract against Dengue virus infection in human blood-derived macrophages," Phytomedicine, vol. 15, no. 10, pp. 793-799, 2008.

[187] K. Zandi, T. H. Lim, N. A. Rahim et al., "Extract of Scutellaria baicalensis inhibits dengue virus replication," BMC Complementary and Alternative Medicine, vol. 13, no. 1, pp. 91-91, 2013.

[188] D. Kumar, G. Kumar, and V. Agrawal, "Green synthesis of silver nanoparticles using Holarrhena antidysenterica (L.) Wall.Bark extract and their larvicidal activity against dengue and filariasis vectors," Parasitology Research, vol. 117, no. 2, pp. 377-389, 2018.

[189] U. Muthukumaran, M. Govindarajan, M. Rajeswary, and S. L. Hoti, "Synthesis and characterization of silver nanoparticles using Gmelina asiatica leaf extract against filariasis, dengue, and malaria vector mosquitoes," Parasitology Research, vol. 114, no. 5, pp. 1817-1827, 2015.

[190] V. Roa-Linares, Y. Miranda-Brand, V. Tangarife-Castaño et al., "Anti-herpetic, anti-dengue and antineoplastic activities of simple and heterocycle-fused derivatives of terpenyl1,4-naphthoquinone and 1,4-anthraquinone," Molecules, vol. 24, no. 7, p. 1279, 2019.

[191] H.-T. Huang, C.-C. Lin, T.-C. Kuo, S.-J. Chen, and R.N. Huang, "Phytochemical composition and larvicidal activity of essential oils from herbal plants," Planta, vol. 250, no. 1, pp. 59-68, 2019.

[192] C. Jasso-Miranda, I. Herrera-Camacho, L. K. Flores-Mendoza et al., "Antiviral and immunomodulatory effects of polyphenols on macrophages infected with dengue virus serotypes 2 and 3 enhanced or not with antibodies," Infection and Drug Resistance, vol. 12, pp. 1833-1852, 2019.

[193] D.-L. Wu, H. J. Li, D. Smith et al., "Polyketides and alkaloids from the marine-derived fungus dichotomomyces cejpii F31-1 and the antiviral activity of scequinadoline A against dengue virus," Marine Drugs, vol. 16, no. 7, p. 229, 2018.

[194] A. M. S. Ahmed, R. A. I. Abou-Elkhair, A. M. el-Torky, and A. E. A. Hassan, "3-Trifluoromethylpyrazolones derived nucleosides: synthesis and antiviral evaluation," Nucleosides, Nucleotides \& Nucleic Acids, vol. 38, no. 8, pp. 590-603, 2019.

[195] S. A. Abdul Ahmad, U. D. Palanisamy, J. J. Khoo, A. Dhanoa, and S. Syed Hassan, "Efficacy of geraniin on dengue virus type-2 infected BALB/c mice," Virology Journal, vol. 16, no. 1, p. 26, 2019.

[196] Z. Sugiyanto, B. Yohan, S. Hadisaputro et al., "Inhibitory effect of alpha-mangostin to dengue virus replication and cytokines expression in human peripheral blood mononuclear cells," Natural Products and Bioprospecting, vol. 9, no. 5, pp. 345-349, 2019.

[197] M. Tarasuk, P. Songprakhon, P. Chimma, P. Sratongno, K. Na-Bangchang, and P.-t. Yenchitsomanus, "Alpha-man- gostin inhibits both dengue virus production and cytokine/ chemokine expression," Virus Research, vol. 240, pp. 180189, 2017.

[198] M. Bourjot, P. Leyssen, C. Eydoux et al., "Chemical constituents of Anacolosa pervilleana and their antiviral activities," Fitoterapia, vol. 83, no. 6, pp. 1076-1080, 2012.

[199] J. S. Y. Low, K. X. Wu, K. C. Chen, M. M.-L. Ng, and J. J. H. $\mathrm{Chu}$, "Narasin, a novel antiviral compound that blocks dengue virus protein expression," Antiviral Therapy, vol. 16, no. 8, pp. 1203-1218, 2011.

[200] J. M. Crance, N. Scaramozzino, A. Jouan, and D. Garin, "Interferon, ribavirin, 6-azauridine and glycyrrhizin: antiviral compounds active against pathogenic flaviviruses," Antiviral Research, vol. 58, no. 1, pp. 73-79, 2003.

[201] L. A. Baltina, Y. T. Tasi, S. H. Huang et al., "Glycyrrhizic acid derivatives as dengue virus inhibitors," Bioorganic \& Medicinal Chemistry Letters, vol. 29, no. 20, article 126645, 2019.

[202] M. Zasloff, A. P. Adams, B. Beckerman et al., "Squalamine as a broad-spectrum systemic antiviral agent with therapeutic potential," Proceedings of the National Academy of Sciences of the United States of America, vol. 108, no. 38, pp. 1597815983, 2011.

[203] A. Rahman, S. Muliawan, N. Rashid, and Y. Muhamad, "Studies on Quercus Iusitanica Extract on DENV-2 Replication," Dengue Bulletin, vol. 30, pp. 260-269, 2006.

[204] M. Bourjot, P. Leyssen, C. Eydoux et al., "Flacourtosides A-F, phenolic glycosides isolated from Flacourtia ramontchi," Journal of Natural Products, vol. 75, no. 4, pp. 752-758, 2012.

[205] D. Laurent, F. Baumann, A. G. Benoit et al., "Structure-activity relationships of dengue antiviral polycyclic quinones," The Southeast Asian Journal of Tropical Medicine and Public Health, vol. 36, no. 4, pp. 901-905, 2005.

[206] M. Laille, F. Gerald, and C. Debitus, "In vitro antiviral activity on dengue virus of marine natural products," Cellular and Molecular Life Sciences, vol. 54, no. 2, pp. 167-1670, 1998.

[207] G. C. Brandão, E. Kroon, D. Souza, J. Filho, and A. Oliveira, "Chemistry and antiviral activity of Arrabidaea pulchra (Bignoniaceae)," Molecules, vol. 18, no. 8, pp. 9919-9932, 2013.

[208] P.-M. Allard, P. Leyssen, M. T. Martin et al., "Antiviral chlorinated daphnane diterpenoid orthoesters from the bark and wood of Trigonostemon cherrieri," Phytochemistry, vol. 84, pp. 160-168, 2012.

[209] X. G. Zhang, P. W. Mason, E. J. Dubovi et al., “Antiviral activity of geneticin against dengue virus," Antiviral Research, vol. 83, no. 1, pp. 21-27, 2009.

[210] K. Whitby, T. C. Pierson, B. Geiss et al., "Castanospermine, a potent inhibitor of dengue virus infection in vitro and in vivo," Journal of Virology, vol. 79, no. 14, pp. 8698-8706, 2005.

[211] F. Jia, G. Zou, J. Fan, and Z. Yuan, "Identification of palmatine as an inhibitor of West Nile virus," Archives of Virology, vol. 155, no. 8, pp. 1325-1329, 2010.

[212] J. S. Y. Low, K. C. Chen, K. X. Wu, M. M.-L. Ng, and J. J. H. $\mathrm{Chu}$, "Antiviral activity of emetine Dihydrochloride against dengue virus infection," Journal of Antivirals \& Antiretrovirals, vol. 1, pp. 62-71, 2009.

[213] L. R. Simões, G. M. Maciel, G. C. Brandão, E. G. Kroon, R. O. Castilho, and A. B. Oliveira, "Antiviral activity of Distictella elongata (Vahl) Urb. (Bignoniaceae), a potentially useful source of anti-dengue drugs from the state of Minas Gerais, 
Brazil,” Brazil. Lett Appl Microbiol, vol. 53, no. 6, pp. 602607, 2011.

[214] J. F. Arboleda Alzate, I. A. Rodenhuis-Zybert, J. C. Hernández, J. M. Smit, and S. Urcuqui-Inchima, "Human macrophages differentiated in the presence of vitamin D3 restrict dengue virus infection and innate responses by downregulating mannose receptor expression," PLoS Neglected Tropical Diseases, vol. 11, no. 10, article e0005904, 2017.

[215] M. Jadhav, M. Nayak, S. Kumar et al., "Clinical proteomics and cytokine profiling for dengue fever disease severity biomarkers," Omics: a journal of integrative biology, vol. 21, no. 11, pp. 665-677, 2017.

[216] P. M. Allard, E. T. H. Dau, C. Eydoux et al., "Alkylated flavanones from the bark of Cryptocarya chartacea as dengue virus NS5 polymerase inhibitors," Journal of Natural Products, vol. 74, no. 11, pp. 2446-2453, 2011.

[217] H. Puerta-Guardo, S. I. De la Cruz Hernández, V. H. Rosales, J. E. Ludert, and R. M. del Angel, "The 1 $\alpha, 25$-dihydroxy-vitamin $\mathrm{D} 3$ reduces dengue virus infection in human myelomonocyte (U937) and hepatic (Huh-7) cell lines and cytokine production in the infected monocytes," Antiviral Research, vol. 94, no. 1, pp. 57-61, 2012.

[218] T. G. Floore, "Mosquito larval control practices: past and present," Journal of the American Mosquito Control Association, vol. 22, no. 3, pp. 527-533, 2006.

[219] S. A. Abdul Ahmad, U. D. Palanisamy, B. A. Tejo, M. F. Chew, H. W. Tham, and S. Syed Hassan, "Geraniin extracted from the rind of Nephelium lappaceum binds to dengue virus type-2 envelope protein and inhibits early stage of virus replication," Virology Journal, vol. 14, no. 1, p. 229, 2017.

[220] S. Zaman, "Effectiveness of vitamin D in prevention of dengue Haemorrhagic fever and dengue shock syndrome," Journal of Rawalpindi Medical College, vol. 21, pp. 205-207, 2017.

[221] E. Moghaddam, B.-T. Teoh, S.-S. Sam et al., "Baicalin, a metabolite of baicalein with antiviral activity against dengue virus," Scientific Reports, vol. 4, 2015.

[222] D. M. Giraldo, A. Cardona, and S. Urcuqui-Inchima, "Highdose of vitamin D supplement is associated with reduced susceptibility of monocyte-derived macrophages to dengue virus infection and pro-inflammatory cytokine production: an exploratory study," Clinica Chimica Acta, vol. 478, pp. 140151, 2018.

[223] M. Raekiansyah, C. C. Buerano, M. A. D. Luz, and K. Morita, "Inhibitory effect of the green tea molecule EGCG against dengue virus infection," Archives of Virology, vol. 163, no. 6, pp. 1649-1655, 2018.

[224] Y. B. Cheng, J. C. Lee, I. W. Lo et al., "Ecdysones from Zoanthus spp with inhibitory activity against dengue virus 2," Bioorganic \& Medicinal Chemistry Letters, vol. 26, no. 9, pp. 2344-2348, 2016.

[225] C. Gómez-Calderón, C. Mesa-Castro, S. Robledo et al., "Antiviral effect of compounds derived from the seeds of Mammea americana and Tabernaemontana cymosa on dengue and chikungunya virus infections," BMC Complementary and Alternative Medicine, vol. 17, no. 1, pp. 57-57, 2017.

[226] M. Raekiansyah, M. Mori, K. Nonaka et al., "Identification of novel antiviral of fungus-derived brefeldin A against dengue viruses," Tropical Medicine and Health, vol. 45, no. 1, 2017.

[227] T. Hishiki, F. Kato, S. Tajima et al., "Hirsutine, an indole alkaloid of Uncaria rhynchophylla, inhibits late step in dengue virus lifecycle," Frontiers in Microbiology, vol. 8, pp. 16741674, 2017.

[228] M. Peng, S. Watanabe, K. W. K. Chan et al., "Luteolin restricts dengue virus replication through inhibition of the proprotein convertase furin," Antiviral Research, vol. 143, pp. 176-185, 2017.

[229] Y.-H. Wu, C. K. Tseng, H. C. Wu et al., "Avocado (Persea americana) fruit extract $(2 R, 4 R)$-1,2,4-trihydroxyheptadec16 -yne inhibits dengue virus replication via upregulation of NF- $\kappa$ B-dependent induction of antiviral interferon responses," Scientific Reports, vol. 9, no. 1, p. 423, 2019.

[230] J.-C. Lee, F.-R. Chang, S.-R. Chen et al., "Anti-dengue virus constituents from Formosan Zoanthid Palythoa mutuki," Marine Drugs, vol. 14, no. 8, p. 151, 2016.

[231] S. Bharadwaj, K. E. Lee, V. D. Dwivedi et al., "Discovery of Ganoderma lucidum triterpenoids as potential inhibitors against Dengue virus NS2B-NS3 protease," Scientific Reports, vol. 9, no. 1, article 19059, 2019.

[232] A. C. Nascimento, L. M. M. Valente, M. Gomes et al., “Antiviral activity of _Faramea bahiensis_leaves on dengue virus type- 2 and characterization of a new antiviral flavanone glycoside," Phytochemistry Letters, vol. 19, pp. 220-225, 2017.

[233] N. Sharma, K. P. Mishra, and L. Ganju, "Salidroside exhibits anti-dengue virus activity by upregulating host innate immune factors," Archives of Virology, vol. 161, no. 12, pp. 3331-3344, 2016.

[234] Y. B. Cheng, Y. T. Chien, J. C. Lee et al., "Limonoids from the seeds of Swietenia macrophylla with inhibitory activity against dengue virus 2," Journal of Natural Products, vol. 77, no. 11, pp. 2367-2374, 2014.

[235] J. P. Sales de Almeida, L. S. Liberatti, F. E. N. Barros et al., "Profile of oxidative stress markers is dependent on vitamin D levels in patients with chronic hepatitis C," Nutrition, vol. 32, no. 3, pp. 362-367, 2016. 